\title{
Strategies to Engage Millennial Employees (A Multiple Case Study)
}

\author{
Duane 0. Stephens \\ ECPI University (East Coast Polytechnic Institute), Virginia Beach, VA, USA \\ Email: dstephens508@gmail.com
}

How to cite this paper: Stephens, D. O. (2021). Strategies to Engage Millennial Employees (A Multiple Case Study). Open Journal of Business and Management, 9, 618-658.

https://doi.org/10.4236/ojbm.2021.92033

Received: January 23, 2021

Accepted: March 15, 2021

Published: March 18, 2021

Copyright ( $\odot 2021$ by author(s) and Scientific Research Publishing Inc. This work is licensed under the Creative Commons Attribution International License (CC BY 4.0).

http://creativecommons.org/licenses/by/4.0/

\begin{abstract}
Grounded in Kahn's employee engagement theory, the purpose of this qualitative multiple case study was to explore effective strategies used by leaders in the hospitality industry to improve Millennial employee engagement. The participants were 5 hotel leaders in Virginia who successfully engaged their Millennial workforce. Data were collected from semistructured interviews, company documents, and note-taking. Data were analyzed using Yin's 5-step data analysis, member checking, and methodological triangulation. Four themes emerged: coaching through education, rewards that improve engagement, enhancing engagement through motivation, and communication that enhances awareness and receptiveness. The results of the study indicated that managers could use mentoring, communication, and incentives to engage millennial employees and decrease employee engagement barriers. The implications for positive social change include providing hospitality industry managers with a framework for understanding their Millennial workers that can potentially promote positive relationships and improve employee morale. Employee engagement strategies could potentially lead to an improvement in the societal workforce, reduce unemployment rates, and increase the US economy and tax base.
\end{abstract}

\section{Keywords}

Employee Engagement, Hospitality, Leaders, Millennials

\section{Introduction and Background}

The purpose of this study was to explore the strategies used in the hospitality industry to engage Millennial employees in the workplace. The participants were 5 hotel leaders in Virginia who successfully engaged their Millennial workforce. This study includes three sections. The first section includes the abstract, introduction and background, purpose statement, research question, assumptions, 
limitations, and delimitations and a review of the literature. The second section includes the research method and design, population and sampling, data collection and analysis, and reliability and validity. The third section includes the findings, application to professional practice, recommendations for further action, and conclusion. In the hospitality industry, employee engagement plays a role in the success of the company because engaged employees provide good quality customer service (Karatepe, 2013). An engaged employee in the hospitality industry may increase productivity, increase profits, and improve business outcomes (Putra, Cho, \& Liu, 2017). A disengaged employee may reduce the quality of service; therefore, resulting in customer dissatisfaction (Meng, Reber, \& Rogers, 2017).

Highly engaged Millennial employees have the potential to improve profitability and customer satisfaction in the hospitality industry. Millennial employees may be more engaged at work if they find the job meaningful, interesting, and flexible (Raza, Ansari, Humayon, Hussain, \& Aziz, 2017). Therefore, leaders in the hospitality industry use innovative strategies to improve engagement levels among Millennial employees. Employee engagement is one of the most discussed topics among human-resource professionals and academics as it is an indicator for job performance, turnover, employee intentions, and organizational commitment (Krishnaveni \& Monica, 2016). Furthermore, an engaged employee goes beyond assigned work duties (Anitha, 2014). Engaged employees exceed in productivity because they want to see the organization succeed and want to do their part to ensure its success (Bolino, Hsiung, Harvey, \& LePine, 2015). The workforce is going through a generational shift as the older generations moving to retirement (Kuron, Lyons, Schweitzer, \& Ng, 2015). Individuals born between the mid-1980s and the early 2000s are known as Millennials (Nolan, 2015). Millennials, referenced as Generation Y or trophy kids, consist of about 80,000,000 people who will dominate the workforce in the year 2040 (Anderson, Buchko, \& Buchko, 2016).

Different generations view job involvement, organizational commitment, professional commitment, and team commitment differently because various generations base their view of these concepts on events that happened economically, politically, and socially during their early years (Singh \& Gupta, 2015). Political, economic, and social events develop different and unique undertones in a generation, and these undertones stay with an individual throughout their lifetime (Fishman, 2016). Managers indicated the challenges to maintain Millennial workers (Bannon, Ford, \& Meltzer, 2011). Once managers invest time to recruit, hire, and train Millennials, they may take their talents to another organization (Ferri-Reed, 2014).

\section{Purpose Statement}

The purpose of this qualitative multiple case study was to explore the strategies that some hospitality leaders use to improve Millennial employee engagement. 
This study's target population was leaders of five hotel organizations who have successfully engaged Millennial workers in Virginia. The implications for positive social change from this study include a potential increase in employee confidence and motivation resulting from more effective Millennials' engagement, increasing company revenue, and allowing businesses to attract and retain talented employees. This increase could reduce unemployment rates in the hospitality industry, in all business sectors in Virginia, and strengthen families' financial resources in the various local communities.

\section{Research Question}

The Central Research Question guiding this study was what strategies do some hospitality leaders use to improve employee engagement among Millennial workers? Data derived from semistructured interviews and questionnaires, company documents, and company records.

\section{Assumptions, Limitations, and Delimitations}

Assumptions are information in the study that the researcher believes to be accurate but cannot receive verification (Gandomani, Zulzalil, Ghani, Sultan, \& Parizi, 2015). One assumption for this study was that participants would answer my interview questions truthfully and with sincerity. I expected participants to answer the questions with no motive to design a predetermined outcome intentionally. In addition, the interviews occurred at places of employment or other private locations, where I assumed participants were able to participate without restrictions.

Limitations are external factors that could impede or confine the research scope and may ultimately affect the outcome of the research (Evans III, Feng, Hoffman, Moser, \& Van der Stede, 2015). Successful hotel leaders may limit the research scope because of the exclusion of unsuccessful hotel leaders who are not able to provide strategies to get millenniums to become more engaged. A multiple case study of the selected hotel leaders from Virginia may not represent the population of different hotel leaders or different types of hotels in the United States. The Hotel leaders sample size and in Virginia present limitation that does not reflect other geographical locations.

Delimitations are factors that narrow the research and determine the boundaries of the study (Bloomberg \& Volpe, 2012). The delimitations of this study included hotels in Virginia that had been in operation for at least 3 years and had a minimum of five Millennial generation employees who were full-time employees. I did not consider the engagement strategies of baby boomers or Generation $\mathrm{X}$ employees, but some leaders in the organization fit into those generations. This study did not include participants working in motels.

\section{Significance of the Study}

Organizational leaders may use this study's results to develop recommendations 
and advise other leaders in developing and deploying effective employee engagement strategies. Organizations may retain workers longer by effectively engaging Millennial workers (see McGinnis Johnson \& Ng, 2016). Employees regularly engage and disengage themselves throughout the workday, affecting work commitment and work performance (Brooks \& Califf, 2017; Kahn, 1990).

Employee engagement leads to increased competitiveness and profitability for the company (Barry \& Wilkinson, 2016). Moreover, employee engagement could decrease employee turnover and burnout (Swensen, Kabcenell, \& Shanafelt, 2016). Employees' effective engagement might enhance overall business operations by increasing organizational profitability and creating a better business environment for employees and customers (Mishra, Boynton, \& Mishra, 2014).

The findings from this study may help hospitality leaders use strategies to increase employee confidence and motivation and thereby improve employee engagement among Millennial workers. Hospitality leaders could increase revenue through improved employee engagement, which may ultimately lead to job creation, a reduction in unemployment rates, and greater prosperity for the families who reside in Virginia.

\section{A Review of the Academic Literature}

\section{Employee Engagement Theory}

The conceptual framework for this study was employee engagement theory, which focuses on employee behavior throughout the workday as employees engage and disengage during their job performance (Kahn, 1990). In the theory of employee engagement, Kahn (1990) discussed the employee's engagement level through their commitment to the organization. The theory of employee engagement was essential to counteract the old ways of thinking and practices managers used to engage employees. The factors that affect an employee's level of commitment to the organization could reveal an index of motivators to boost employee engagement (Schmitt, Den Hartog, \& Belschak, 2016).

Personal engagement occurs when employees assert themselves fully in fulfilling their work roles (Kahn, 1990). Engaged employees do not spend time focusing on anything other than work and how to better their performance or work environment (Jensen, 2017). Additionally, employees who engage are working to improve the organization with their talent (Christensen Hughes \& Rog, 2008). Employees' own experiences impact their commitment level, how they are involved with the organization and their performance level. Employee involvement or lack of involvement in an organization is an attribute in the employee engagement theory (Kahn, 1990).

In contrast, employee disengagement occurs when employees withdraw themselves and do not work to better the organization (Kahn, 1990). In this case, employees spend time thinking of solutions to problems outside of work and spend more time withdrawn from the organization (Sonnentag \& Fritz, 2015). Leaders who understand employee engagement principles could help employers 
establish tools to analyze better how employee engagement affects an organization (Milliken, Schipani, Bishara, \& Prado, 2015).

Kahn's theory of employee engagement includes explaining the level of commitment and engagement employees experience while working for specific organizations (Bal \& De Lange, 2015; Jin \& McDonald, 2017; Kahn, 1990). Employees engage on emotional, physical, and intellectual levels (Kahn, 1990). Manager evaluations of critical hotel industry objectives reveal a correlation between engagement methods, the organization's success, and productive employees (Jin \& McDonald, 2017).

\section{Employee Engagement and Job Performance}

Employee engagement and job performance are related (Rich, Lepine, \& Crawford, 2010). Engaged employees tend to operate at a higher level of proficiency. A review of an employee's work history may indicate if positive work experiences helped the employee understand their role in the organization and perform at or above expectations (Conway, Fu, Monks, Alfes, \& Bailey, 2016). Employees who feel heard by management tend to be more concerned with the organization's success (Bolino \& Grant, 2016). Employees who have input about the organization's future direction feel empowered and tend to make decisions based on the organization's objectives (Bolino \& Grant, 2016). Employees who make key organizational decisions can potentially feel a sense of empowerment, belonging, and engagement.

Organizational leaders who recognize the connection between employee engagement and job performance can connect employee engagement to the organization's overall success. Leaders who understand the relationship between employee engagement and job performance can identify the organization's least effective policies and adjust them accordingly (Wiliam \& Thompson, 2017). Leaders can use surveys or employee suggestion boxes to understand ways to engage employees better and gauge the overall effectiveness of changes. The results of these surveys can aid leadership in adjusting the overall decision-making process based on employee feedback. Leadership can better understand work outputs such as productivity and customer satisfaction when they understand the relationship between employee engagement and job performance (Bowling, Khazon, Meyer, \& Burrus, 2015).

Managers who work to build a strong and successful team understand that employees must be motivated appropriately (Ford, Piccolo, \& Ford, 2017). Employees who cannot see the value in their efforts may feel taken for granted and might not work to achieve success in the organization (Raghuram, Gajendran, Liu, \& Somaya, 2017). Managers should work to motivate and communicate the overall objectives for their employees. Managers who build loyalty and confidence with their team could potentially benefit from a group of high performers.

Employees who pride themselves on achieving the organizational goals and work toward successfully executing their vision have fully committed themselves to the organization (Dechawatanapaisal, 2018). These employees take pride in 
their job performance and work hard to maintain both their success and the organization's success (Van Wingerden, Derks, \& Bakker, 2017). Managers could consider recognizing when an employee wants to excel in the organization and help that employee grow; employee growth benefits the employee and the organization.

An engaged employee may do all the necessary things to keep the organization moving forward (Crosina \& Pratt, 2019). An organization moving forward maintains high levels of employee engagement, customer service, customer satisfaction, innovation, and profitability (Menguc, Auh, Yeniaras, \& Katsikeas, 2017). Managers must continue to keep employees engaged, as an engaged employee will have better job performance and continue to push the organization forward. Organizations continue to thrive when their employees outperform their competition (Walumbwa, Muchiri, Misati, Wu, \& Meiliani, 2018). One facet of employee engagement includes employees' putting extra effort into their jobs, having a sense of pride and loyalty working for an organization, and advocating for the organization.

\section{Millennials (Generation Y Members)}

Millennials, also known as Generation Y, were born in the mid-1990s to early 2000s (Lyons \& Kuron, 2014). Millennials are most notably known for being driven by social issues and attitudes toward work (Ertas, 2015). Millennials are lazy and less willing to commit to an employer; therefore, millennials move from employer to employer with no loyalty to any particular one (Dziewanowska, Pearce, \& Zupan, 2016).

Millennials work for organizations that respect work-life balance and employers that offer flexible work schedules (Bennett, Beehr, \& Ivanitskaya, 2017). Millennials will be the largest generation in the workforce as the older generations move into retirement (Hoyle, 2017). To retain Millennial employees, employers must learn Millennials' work habits, understand what drives Millennial employees, and speak the same language as the Millennial worker (Jassawalla \& Sashittal, 2017).

The Millennial generation has a better understanding of new technologies and social media. Millennials use social media as their primary source of communication and engagement with coworkers, friends, and family members (Beam, Child, Hutchens, \& Hmielowski, 2018). Social media is the quickest way to communicate with a larger audience while delivering the same message simultaneously (Key \& Czaplewski, 2017). Technology and social media could be drivers of engagement among Millennials, and companies could incorporate technology and social media to engage their Millennial workforce. Employers that incorporate current communication channels with innovation through social media will have a greater opportunity for a successful connection with Millennials (Pucciarelli \& Kaplan, 2016).

Employee Engagement in the Hospitality Industry

Varying accommodation models in the hospitality industry are to satisfy to- 
day's leisure and business travelers (Blal, Singal, \& Templin, 2018). Families rent rooms within their own homes with platforms such as Airbnb, in addition to using traditional accommodations such as hotels and motels (Gurran \& Phibbs, 2017). Travelers have many options for places to stay; therefore, travelers consider the cost of accommodation and traveling distance when making final itinerary decisions. In addition, travelers consider the experiences gained from workers from their place of stay. The industry must consider how it connects with prospective travelers through organizational employees to keep hotels and motels the best option for travelers (Zervas, Proserpio, \& Byers, 2017). Employees are the frontline connection to guests, and employee engagement will be evident in the type of service they provide to patrons (Cain, Tanford, \& Shulga, 2018).

Hospitality managers have challenges attracting qualified employees and subsequently retaining them (Kim, Knutson, \& Choi, 2016). Managers redirect their focus to other issues such as challenging work conditions, high employee turnover, and the influx of younger workers (Serini, Toth, Wright, \& Emig, 1997). Employers need strategies to effectively engage employees for the industry to continue to thrive and adequately service customers.

\section{Leadership Strategies}

Leadership must get creative when addressing the Millennial worker. The idea that Millennials will stay with an employer for good benefits and stability is a past work motivator (Glazer, Mahoney, \& Randall, 2019). Millennials look for jobs where they can make a difference and follow a cause, usually a cause with which they have a connection (Crosby \& Bryson, 2018). Leaders must identify new strategies and become creative when attracting and retaining the Millennial worker, therefore, creating an opportunity for established companies to retool themselves to connect with a younger and savvier consumer.

One of the first changes organizations made to recruiting and business benefits were introducing the $401 \mathrm{~K}$ plan to replace traditional pension plans (Thaler, 2016). Pensions are used less often as a recruiting tool; instead, employers are making employees more active in preparing their financial portfolio for future retirement (Cheah et al., 2015). The absence of the retirement pension incentive works well with the Millennial worker because Millennials usually do not stay at one company long enough to receive a pension (Börsch-Supan \& Weiss, 2016). In this way, society seems to align with the transient mindset of Millennials.

The inspiration for new initiatives for Millennials comes from listening to what Millennials have to say and understanding what factors shaped them when they were growing up. People may receive answers concerning questions about individuals and groups of individuals can be answered by considering the history of the individual or group (Fischer et al., 2018). Managers can find valuable information about motivating Millennials when considering Millennials' past (O'Connor \& Raile, 2015). To uncover revelations about Millennials, managers need to consider what was happening during Millennials' rearing years closely. 
The various generations that now occupy the workforce differ, and managing those differences is vital in today's business environments (Milligan, 2016). Managers who can effectively communicate with the multigenerational workforce can assist in creating strategies to help organizations thrive. Managers can use the following tactics to engage a multigenerational workforce and keep them productive effectively: improving communication, improving how employees see themselves fitting in the organization, and building greater trust with employees (Woods, 2016). Employees will be more productive if they view themselves as important parts of the organization (Menges, Tussing, Wihler, \& Grant, 2017).

Organizational leaders who encourage collaboration, create a flexible work environment, understand and respect work-life balance, have a system in place for educational opportunities, and provide feedback and recognition for work performance will benefit from a more productive and engaged multigenerational workforce (Walumbwa et al., 2018). Managers who maintain a close connection to the workforce can quickly address issues as they arise (Hayes, Parks, McNeilly, \& Johnson, 2018).

Organizations should continue to train employees and develop programs to increase positive interaction among a multigenerational workforce (Richardson, 2017). Employees will gain a better understanding of the members of generations with whom they work when organizations implement programs to develop better cohesiveness among workers of different generations (Argote \& Guo, 2016). Building a better understanding of differences in the workforce will allow the organization's leadership to adjust leadership styles to increase work quality, productivity, and overall employee morale (Bolino, Klotz, \& Turnley, 2016). Understanding the different generations' actions and behaviors can create and foster better relationships among employees (Methot, Lepine, Podsakoff, \& Christian, 2016).

Employees can work behind their generational counterparts to familiarize themselves with the roles employees of other generations fill and to get to become better acquainted with their colleagues (Lim, 2016). Starting a mentoring program for Millennial workers would allow Millennials to work with baby boomers, enabling the two generations to work more harmoniously and foster better communication in a multigenerational workplace (Flynn \& Duesing, 2020). Millennials have the following expectations regarding working compensation, recognition, promotions, professional growth opportunities, manager support, and flexibility from an employer. In exchange, managers expect Millennials to do their job (Duxbury \& Ormsbee, 2020). The different generations share some similarities and display some differences; however, the collaboration between generations can yield overall organizational success. The integration of the most effective strategies determines whether managers are successful in engaging Millennials and a multigenerational workforce.

To attract talented Millennial workers, leaders must be more creative in at- 
tracting and managing new talent. Leadership must understand that motivational factors change from generation to generation (Singh, 2016). Millennial generation workers like to express individuality and recognize different causes (Risman, 2017). Leadership should consider the Millennial generation's mobility and realize that Millennials will leave their current employer to work at another company if the other company supports a cause or allows the employee to support the cause without jeopardizing their employment (Bannon et al., 2011). Today's Millennial worker wants to be understood and supported. Organizational leadership must create innovative ways to allow Millennial employees to fit in the work culture without sacrificing their identity.

Organizational leaders could examine multigenerational workforce equal opportunity to offer ideas and express Millennial views through the lens of organizational goals and processes. The Millennial generation is the hospitality industry's future; therefore, leaders may target Millennial worker motivations to create more productive workers (Singh, 2016). An understanding of Millennial motivators could create a more productive work environment (Methot et al., 2016), resulting in more satisfied customers and higher revenue for the organization (Thompson \& Gregory, 2012). Leaders who pay attention to Millennial workers and use innovative ways to engage Millennials will create a loyal workforce (Kang \& Sung, 2017). Additionally, leaders could gain from Millennial employees' knowledge and ideas for innovation, organizational communication, and process improvement.

\section{Research Method and Design}

A researcher who selects an appropriate research method and design establishes a necessary means to conduct a credible study (Venkatesh, Brown, \& Sullivan, 2016). I chose the appropriate research method and design for this study to establish credibility. The research method and design I chose for this study were the qualitative and multiple case-study designs. The qualitative case study provides a means to explore the best strategies for improving employee engagement among Millennial workers in the hospitality industry.

\section{Research Design}

I selected a case study design for this research. The case study design is suitable when the research question requires a more in-depth look at a phenomenon (Yin, 2018). A case study design can expand readers' knowledge of an individual, group, social, political, or organizational phenomenon. A case study research design is useful when various data sources are available, such as artifacts, documents, observations, and interviews (Yin, 2018). A case study design's statistical approach is to allocate aggregated levels from the ordinal type ordered quantitative survey answers (Yin, 2018).

Failure to achieve data saturation in a qualitative study significantly affects the quality and the overall validity of a study (Fusch \& Ness, 2015). Data saturation occurs in case studies using interviews, company documents, and physical arti- 
facts (Merriam \& Tisdell, 2015). One purpose of member-checking can ensure that no new information occurs. The lack of further details indicates data saturation (Hammarberg, Kirkman, \& De Lacey, 2016). The member-checking process involves reviewing the information collected during interviews with participants to allow participants an opportunity to elaborate on their responses (Morse, 2015). I requested company documents, asked participants open-ended interview questions, and asked participants to elaborate on their responses until no new information materialized. I ensured data saturation by interviewing all participants and comparing the collected information and documents. Next, I conducted member-checking by providing the participants with my interpretation of their responses and allowing participants time to review and respond for accuracy and validation.

\section{Population and Sampling}

The population for this qualitative multiple case study consisted of managers from five hotels in Virginia. The minimum criteria for participation were as follows: 1) participants must work in the hospitality industry in Virginia for a minimum of 3 years, 2) participants must serve in a leadership position, 3) participants were not Millennials, and 4) participants supervise Millennial employees. The participants were managers of Millennial workers who have successfully used strategies to engage Millennial employees. Hotel managers who met these criteria were able to reflect on their experiences and current knowledge of working with Millennial employees. I used qualitative research to explore employee engagement in the hospitality industry and discovered strategies to engage Millennial hospitality workers effectively.

I used the purposive sampling method for this study. Purposive sampling is the preferred method of participant selection when exploring an issue, question, or dilemma (Robinson, 2014). Purposive sampling is effective because it can use a small sample size of participants who may share the same mindset and similar attributes and convictions (Barbour, 2013). Purposive sampling is the favored selection method to examine a phenomenon (Elo et al., 2014). The sampling technique was appropriate for this study because of its convenience in selecting participants who were knowledgeable in Millennials' employee engagement and who were easily accessible to participate.

Case studies can have three to five participants (Yin, 2018). A multiple case study should have a large enough sample size to achieve the required results. A multiple case study with a small sample size and appropriate interview questions can comprise a successful study (Fink, 2015; Morse, 2015) and provide the researcher with an in-depth understanding of the phenomenon (Malterud, Siersma, \& Guassora, 2016). I limited the sample size for this multiple case study to achieve the necessary results and develop an in-depth understanding of the phenomenon.

Data saturation occurs in a study when no new information or additional 
themes emerge after interviewing participants (Guest, Namey, Taylor, Eley, \& McKenna, 2017). The key points to data saturation are 1) no new data emerges (Gentles, Charles, Ploeg, \& McKibbon, 2015), 2) no new themes develop (Malterud et al., 2016), and 3) the reproduction of the study is achievable with ample information (Heckemann, Breimaier, Halfens, Schols, \& Hahn, 2016). Data saturation can develop by interviewing three to 50 participants (Constantinou, Georgiou, \& Perdikogianni, 2017; Yin, 2018). Data saturation is critical because it can reveal possible themes through the exhaustion of information (Fusch \& Ness, 2015). Cypress (2017) posited that member checking is a way to ensure data saturation. I reviewed responses from the interviews, employer training materials, and member-checking to ensure data saturation.

Managers listed in the hotel directory at one hotel received an invitation to participate in the study until I reached the required number of study participants. I contacted the front-line hotel person or corporate office to get permission to speak with the hotel manager. Then, through a brief conversation, I invited managers from five different hotels to participate in the interview to reach the target of at least five participants for this multiple case study, as suggested by Yin (2018). Inviting managers at each hotel ensured that I accrued the sample size needed to complete this study. I ceased inviting managers when I received the minimum number of interested participants to reach data saturation. Interviews were conducted with hotel leaders during hotel leaders' break time, slow time, or lunch hour. If participants were unavailable to meet during those times, I requested to conduct interviews through video calls or face-to-face interviews after their workday. The interviews were semistructured and included open-ended questions in a comfortable setting for the participant. Kolar, Ahmad, Chan, and Erickson (2015) suggested conducting the interviews in a relaxed environment for the participants, with the preference being a face-to-face meeting (Denzin, 2017). I suggested that the interviews take place in a private office or a conference room at the participants' place of work. I made every effort to accommodate other meeting places that participants suggested.

\section{Data Collection Instruments}

The researcher is the primary data collection tool or instrument (Kahn, 1990) and collects various data forms when conducting a case study (Yin, 2018). I was the primary collection tool for this study; therefore, I needed to collect various data forms to complete this case study. Two types of collection methods can be used: semistructured interviews and questionnaires (Unluer, 2012). Semistructured interviews were the primary data source for this study, and I conducted these interviews with hotel managers who had successfully supervised Millennial employees. The semistructured interviews used open-ended questions and were conducted in a relaxed setting suggested by participants. The use of open-ended questions enabled participants to discuss their lived experiences (Soss, 2015) freely. Semistructured interviews are instrumental in collecting the information 
needed to conduct a study (Hancock \& Algozzine, 2016).

I used semistructured interviews to explore the concepts in this study. Interviews consist of collecting data by asking questions and listening to individuals' responses. In semistructured interviews, researchers use predetermined questions to reveal information, and participants reveal more details throughout the interview (Peters \& Halcomb, 2015). The semistructured interview for this study included questions that elaborated on employee engagement levels among Millennial workers. Interviewers use semistructured interviews to gain greater control over the order and flow of questions and to introduce changes in the interview schedule based on initial results (Wildavsky \& Hammer, 2018). Semistructured interviews may produce robust data that understand participants' experiences, views, or ideas (Peters \& Halcomb, 2015).

I reviewed company documents that included training manuals with archival data or company artifacts regarding employee engagement strategies or initiatives. Company artifacts are company documents (Marshall \& Rossman, 2016); therefore, I used company documents related to this topic of employee engagement. As another source of data, I collected company records, such as the employee training manual, directly related to the company's efforts to engage Millennial employees. Company documents or company records are essential to a case study, as they are specialized, stable, and timeless (Yin, 2018). For this reason, I requested to review the employee handbook and any training materials that are directly related to employee engagement.

The interview protocol included questions geared to identify strategies used to improve employee engagement among Millennial workers. I created the interview questions to address barriers to improving employee engagement among Millennials in the hospitality industry. The interview protocol served as the guideline for the inquiry-based conversation and consisted of various questions and scripts with prompt queries and possible follow-up questions (Zielinski, 2017). Interview protocols organize and document important information for the interviewer to ask during the interview (Jaskiewicz, Combs, \& Rau, 2015). An acceptable interview protocol is an essential method for obtaining the best information from study participants (Namey, Guest, McKenna, \& Chen, 2016). The interview protocol is an instrument used by the interviewer to discuss the aim of the study and inquire about specific topics (Castillo-Montoya, 2016). Yin (2018) recommended that researchers can use an interview protocol to manage and organize the interview questions and determine if each interview question is essential to the research question. Study participants received a copy of the interview protocol at the interview time to keep for their records.

I used an interview protocol, member-checking, and data triangulation to ensure the information's validity and reliability. Member-checking involves sharing the researcher's summary of a participant's responses with the corresponding participant to ensure that the information was accurately captured (Koelsch, 2013). Granting the participants access to the final summary to validate their 
responses helps improve the accuracy, credibility, validity, and transferability of a study (Ranney et al., 2015). I collected data from volunteers who participated in the research. An interview protocol ensured consistency between participant responses. I asked colleagues in similar job positions in different organizations to review the interview questions. Researchers should use feedback from colleagues to determine whether the interview questions are well-defined, clearly understood, presented consistently, and properly align with the research purpose (Goldberg \& Allen, 2015). A pilot study is a simplified variation of the main study that can be used to test the interview questions and the theory, yielding a more robust study (Armstrong \& Rimes, 2016). I did not conduct a pilot study because it could eliminate the process completing the primary study. Data triangulation was conducted using the interview responses, the employees training manual, and the information received from member-checking. Data triangulation ensures that the data collection instruments align with the questions in the study (Yin, 2018). Researchers who use data triangulation, member-checking, and the interview protocol enhance the study's validity and reliability (Yazan, 2015).

\section{Data Collection Technique}

Semistructured interviews were the primary data collection technique in this qualitative research study. I visited multiple hotels in Virginia and asked for the manager's contact information. The hotel managers I selected to participate in the study received an email invitation requesting their permission to participate. I scheduled an interview with five managers from five hotels for face-to-face interviews. Hotel managers who agreed to be part of the study were interviewed at their place of employment. Researchers need to conduct face-to-face interviews where the participants feel comfortable (James, 2016) to allow for an in-depth and open conversation (Fritz \& Vandermause, 2018). I did not begin to collect data until I received approval from the Walden Institutional Review Board with an approval number.

Before the interviews, I notified the participants that the interviews would be recorded using Dragon Naturally Speaking software. I informed participants that I would take notes during the interview and only record information about the interview. All participants answered the same open-ended interview questions and had an opportunity to ask questions about the interview if needed. I organized participants' responses by date of interview, the interview location, their position in the organization and added a pseudonym to separate and identify participant responses after the interview sessions.

Digital recording is the most common method of recording interview data because the digital recorder allows the interviewer to save the interview's verbal part for later analysis (Namey et al., 2016). I used a digital recorder with an external memory card slot to record the interview and additional side conversations. Digital recordings are generally better quality and include more detail than 
note-taking, which may not be entirely accurate (Bailey, 2008). I used an external memory card to transfer the audio interviews into a computer efficiently. I performed member-checking by interpreting what I heard the participants say and then allowing the participants the opportunity to validate my interpretation of the voice recordings. I recorded the conversations that occurred during the interview; therefore, I had a chance to synthesize the conversation, which I reviewed later for accuracy and completion (Clark, Birkhead, Fernandez, \& Egger, 2017).

Data were collected by listening to and recording participants' responses during an approximately 45-minute interview. The semistructured interviews included questions geared toward identifying strategies managers use to increase employee engagement among Millennial workers. The use of face-to-face interviews allowed me to ask follow-up questions to clarify answers to the research questions and focus on body language when it appeared that a participant looked confused and needed further explanation (Garbarski, Schaeffer, \& Dykema, 2016). I interpreted verbal and nonverbal messages to ensure participants fully expressed their responses, and I rephrased questions and pursued a different line of questioning when necessary to ensure that participants fully understood the question (Namey et al., 2016). I monitored tone and word choice changes to gain a deeper understanding (Petr, Belk, \& Decrop, 2015). Face-to-face interviews are helpful because they establish rapport and help participants feel more comfortable and at ease, generating more insightful responses, especially regarding sensitive topics (Devotta et al., 2016).

One advantage of semistructured interviews is collecting complete information with greater understanding (Peters \& Halcomb, 2015). Interviews as a data collection technique can gather more in-depth and robust information from fewer participants (Marshall \& Rossman, 2016). All participants were asked the same questions; however, the wording, order, and the type of follow-up questions varied (Peters \& Halcomb, 2015) depending on whether a participant needed more clarity or if I required additional information to fully exhaust the question and reach data saturation. I asked the same questions in the same order as listed in the interview protocol. Additionally, I took notes and requested relevant company documents as a part of data collection for this research study. The semistructured interviews were advantageous because 1) the interviews were conducted in a place that was familiar to the participant, 2) the participant was comfortable and relaxed, and 3) the interviews could foster relaxed conversation (Wolgemuth et al., 2015).

A semistructured interview can be disadvantageous because interview answers are difficult to compare and the flexibility of the conversation may lessen reliability (Rowley, 2012). In addition, semistructured interviews can 1) interfere with participants' schedules (McIntosh \& Morse, 2015), 2) cause participants to withhold information due to timidity and shyness (Seifert, 2016), 3) contain ambiguous research questions (Wolgemuth et al., 2015), and 4) give faulty results if 
the researcher cannot conduct an interview (Malterud et al., 2016). However, interviews have a higher quality of sampling than other data collection methods and require fewer participants to reveal useful and relevant insights (Cyr, 2016). Therefore, I choose semistructured interviews with open-ended questions as the primary data collection technique to gather managers' perspectives in the hospitality industry.

Member-checking is essential to the research process, as participants have the opportunity to add, delete, and edit any captured information (Birt, Scott, Cavers, Campbell, \& Walter, 2016). I conducted member-checking for each participant by emailing each participant a copy of their interview summary and setting up a follow-up interview. Participants received a summary of the interview findings, which were thoroughly reviewed and validated for accuracy. I was able to review, edit, and make any needed changes by sharing my interpretation with the participants for validation. Next, I met with the participants for a 30-minute follow-up interview to validate results and to provide an opportunity for participants to reflect on personal experiences, therefore creating potential opportunities to add data. I focused on the confirmation, modification, and verification of the interview transcript during the follow-up interviews. Member-checking ensures the information is accurately noted, which is different from a transcript review where the interview is verbatim in written form (Tsai et al., 2016).

\section{Data Organization Technique}

Data organization should reflect a manner that achieves the research's overall objective (Rabiee, 2004). Data should be stored in two separate databases: one to document the report and the other for the collected data (Yin, 2018). An important first step in data collecting is to observe the participants closely through repeated careful listening and observation (Lapadat \& Lindsay, 1999). The first set of data for this study consisted of all data recorded during the interview. During the interview, I included journaling based on my observations of the participant, such as the participant's impressions and body language and any observations or ideas that emerged during the data collection. The second set of data included the hotels' training manuals about employee engagement. To protect identities, I referred to individuals using codes: M1, M2, M3, M4, and M5. I referred to the hotel names using the following alphanumeric codes: N1, N2, N3, N4, and N5.

I included a coding process to identify similar themes that emerged from the data from the recorded interviews, handwritten notes, and the training manuals. I uploaded the interview into Dragon Naturally Speaking software to transcribe the interviews and ensure accuracy. Statistical software can aid in coding and organizing during the data analysis process (Sotiriadou, Brouwers, \& Le, 2014). I uploaded the interview recording into NVivo software, which allowed me to store the information based on similar themes. 


\section{Data Analysis}

This qualitative multiple case study aimed to explore strategies hotel managers use to engage Millennials employees. Data analysis is an iterative means of saturating oneself in the data (Hennink, Kaiser, \& Marconi, 2017). Qualitative data analysis occurs in three stages: 1) the introductory saturation into the data, 2) the secondary assemblage of codes and formation of themes, and 3) the final approval of themes and analysis of results (Bernard, 2017). Qualitative data analysis steps are scaling down, incorporating, and certifying or authenticating (Scholl, Kubicek, Cimander, \& Klischewski, 2012). The means of coding is repetitive and comprises at least two cycles of codes with more cycles added if needed (Sarkis et al., 2016). Provisional coding lists predetermined themes that build on existing research (Koro-Ljungberg, 2015).

I used the findings from previous research and opinions from the study participants to check the validity and understand participants' opinions about the phenomena; this process is referred to as data triangulation. The four triangulation types are methodological triangulation, environmental triangulation, investigator triangulation, and theory triangulation (Joslin \& Müller, 2016). I used methodological triangulation to compare various sources of data (Kern, 2018). Methodological triangulation can be used to compare various sources of data using the same method, ensure consistency, increase credibility, and reduce research bias (Flick, 2017). Methodological triangulation can also be used to achieve data saturation and form a valid research project (Fusch \& Ness, 2015). I used methodological triangulation to cross-check data for consistency, reduce bias, and add credibility to my analysis. I reached credibility by methodological triangulation using interviews, employer documents, and interview transcripts.

This study's data sources consisted of interview responses, notes from the interviews, and company training manuals. Various forms of evidence can be assembled to reach conclusions and thereby establish credibility (Yin, 2018). The interview protocol is a step-by-step instructional tool for note-taking and guidance during each interview (Lamb, Orbach, Hershkowitz, Esplin, \& Horowitz, 2007). The interviews were recorded with a digital recorder using the interview protocol as a guide and were transcribed using Dragon Naturally Speaking software. I conducted member-checking for each participant by emailing each participant my interpretation of the interview and providing participants with a timeframe to email me with any edits or changes to my interpretation. I reviewed the interview interpretation or member-checking information, the notes that I recorded related to body language or voice inflection, and any given training materials. I used statistical software to extract common themes for my data analysis.

I uploaded the digital interviews and the review of documents into NVivo after completing the member-checking process. Qualitative research software can be used to assist with data analysis (Woods, Paulus, Atkins, \& Macklin, 2016). 
Descriptive coding is where a phrase or word is used to classify and organize the data and can be traced back to the original code (Vaismoradi, Jones, Turunen, \& Snelgrove, 2016). After the first cycle of coding, second cycle codes-such as pattern coding - can be used to organize first cycle codes into themes or sets (Dillaway, Lysack, \& Luborsky, 2017). I generated nodes in NVivo for underlying ideas for each research question to code the data and authenticate themes. Next, I selected the common themes for each research question based on the participants' responses.

I used the information gathered using NVivo data analysis software and employee engagement theory to answer the research question and analyze the data. NVivo qualitative data analysis software assists researchers in coding, classifying and formulating emerging themes (Davidson, Thompson, \& Harris, 2017). The foundation for a complete review and determination of information gathered from NVivo was the parallel between key primary themes and the conceptual framework (Bandara, Furtmueller, Gorbacheva, Miskon, \& Beekhuyzen, 2015). The parallel between the primary themes and the conceptual framework relates to employee engagement theory and the central research question (Lehnert, Craft, Singh, \& Park, 2016). The foundation of employee engagement theory is the evaluation of engagement or disengagement of employees and their commitment level to achieving the organization's goals (Kahn, 1990). The central or primary research question was as follows: What strategies do some hospitality leaders use to improve employee engagement among Millennial workers?

After collecting the data, I reviewed all participant responses to familiarize myself with the data. I transcribed the interviews using Dragon Naturally Speaking software and uploaded the transcription into NVivo software. I created codes and nodes consistent with the research questions, noted the themes that emerged, and presented the findings. Upon conclusion of the data analysis, I interpreted the data findings based on the common themes derived from NVivo. I used methodological triangulation to validate the data findings from NVivo. Researchers who use multiple data sources can find additional benefits from the data rather than using a single data source (Krause, Herbst-Irmer, Sheldrick, \& Stalke, 2015). Researchers should use proper data interpretation techniques to clarify the collected data's analysis and presentation (Clarke \& Braun, 2013). I reviewed the data to arrive at an informed conclusion. As the researcher, I answered the research question by interpreting the data using information obtained from the NVivo analysis and the conceptual framework theories.

\section{Reliability and Validity}

Reliability and validity are fundamental in establishing trustworthiness, demonstrating rigor in the research findings, and ensuring the results are significant and worthy (Yin, 2018). I assured that the methods used to retrieve and secure data were reliable and valid. Dependability is a component of reliability. Credibility, confirmability, and transferability are components of validity. These 
components can strengthen a study.

Reliability is the degree to which an assessment tool produces stable and consistent results (Yin, 2018). Researchers use dependability synonymously with reliability because a reliable study's findings and conclusions can be replicated (Santiago-Delefosse, Gavin, Bruchez, Roux, \& Stephen, 2016). Researchers should avoid including participants with whom they have a relationship because of the potential to add bias to the collected information (Bell, Bryman, \& Harley, 2018). The decision to use participants with whom I do not have a working, personal or professional relationship ensured the data collected's dependability. I performed the member-checking of data interpretation to ensure dependability by providing participants with an opportunity to review and approve my translation or analysis of their interviews. I emailed the participants' responses from their first interview and scheduled a follow-up interview to gather any additional information or clarify any previously given information. I increased the study's reliability by interviewing five hotel managers.

Validity is the result to which a test measures what it claims to measure (Watkins, 2012). The two main types of validity are internal validity and external validity. Internal validity refers to the validity of the measurement and test itself, whereas external validity refers to generalizing the findings to the target population (Watkins, 2012). The validity elements are credibility, confirmability, and transferability in qualitative research (Onwuegbuzie \& Leech, 2007; Riege, 2003; Watkins, 2012). The purpose of validity is to determine how well a test measures what it is purported to measure (Watkins, 2012). Validity is essential in analyzing the appropriateness, meaningfulness, and usefulness of a research study (Watkins, 2012).

For this qualitative study, I focused on employee engagement strategies for Millennial workers in the hospitality industry; therefore, I needed to obtain credible and reliable data to achieve validity. A test must be valid to be considered reliable. I increased the validity for this study by matching the interview questions with the study goals and objectives. The results of my research are meaningless if the results are not valid. Additionally, I obtained feedback from an outside party regarding the interview questions. It is important to have the instrument measure what it is intended to measure so the results can be used to answer the research question.

Researchers attain credibility through the processes of data triangulation and member-checking (Thomas, 2017). Credibility must include the evidence presented's trustworthiness, and the findings must be believable and truthful (Newell \& Goldsmith, 2001). Member-checking can be integrated into research procedures to ensure the collected information is credible (Rosenthal, 2016). I provided each participant with a synthesized copy of their interview responses and allowed each participant the opportunity to amend incorrect translations to contribute to the study's validity. Saldaña (2015) suggested that researchers use member-checking to ensure that the study findings are credible. I used mem- 
ber-checking to interpret the data.

The use of an interview protocol aids in obtaining credibility (Lamb et al., 2007). For this qualitative research, I used the interview protocol as a systematic way to interview all participants. Each interview followed the same criteria and script while asking the same line of questioning, as suggested by Padgett (2017). The use of the interview protocol in this study established credibility. Credibility focuses on whether the research conveys with certainty what the participants do, feel, or think (Smythe \& Murray, 2000).

Transferability is a component of validity and is vital to the study (Ihantola \& Kihn, 2011). Transferability occurs when the data can transfer from one group to another and provide detailed information about the population sample (Moser \& Korstjens, 2018). Researchers determine if a study is transferable and consistent with the original study by following the same guidelines and asking the same questions. The interview protocol, including detailed information about the setting and location of the research study, approach, and attitudes of participants, will allow another researcher to transfer the information to another group. In qualitative research, the reader determines whether or not the study's findings can transfer to another group. Researchers who follow the criteria of the study can transfer this study's findings to another group. Additionally, an interview protocol can ensure transferability and consistency by asking the same questions and following the same procedures and guidelines (Amankwaa, 2016).

Confirmability exists once plausibility, creditability, and transferability occur (Colepicolo, 2015). A case study is valid when methodological triangulation is achieved (Yin, 2018). In this qualitative research study, triangulation involved examining data from the five interviews. The responses from the five participants were combined to answer the research question. Confirmability refers to the level of confidence that the study findings are based on the participants' narratives and words rather than potential researcher biases (Colepicolo, 2015). Member checking can establish the confirmability of the research elements (Baxter \& Jack, 2008). I confirmed the gathered information by issuing a copy of the synthesized interviews to the participants for review and revisions (Caretta, 2016). Next, I emailed participants a synthesized copy of their interviews and a reminder for the follow-up member-checking process. Member-checking involved another interview session that took approximately 30 minutes and allowed the participants to add any additional information relevant to the study and discuss whether they agreed with the information in the document. Participants made changes as necessary to the finalized document and signed the document for completion of the study. The interview protocol and notes from the interview containing researcher thoughts and reasoning behind certain comments are good tools to help in future explanations (Dumay, 2016). I served as the primary data collection instrument; therefore, I used journaling to guarantee the recorded information's accuracy. 


\section{Findings}

This study's central research question was as follows: What strategies do some hospitality leaders use to improve employee engagement among Millennial workers? Participants were interviewed in either a private conference room or in the participants' office. Data collection consisted of semistructured interviews and note-taking during the interviews. The transcription of and analysis was through using NVivo to identify the themes that emerged from the data. I shared the interpretation of the findings with the participants for validation and conducted member-checking to ensure that participants' answers were accurately recorded during the interviews and to ensure that no new themes or information emerged. Four themes emerged from the data analysis: 1) coaching through education, 2) rewards that improve engagement, 3) enhancing engagement through motivation, and 4) communication enhances awareness and receptiveness. This study's conceptual framework consisted of the employee engagement theory introduced by Kahn (1990); the employee engagement theory helped determine the strategies used to improve employee engagement among Millennial workers. The employee engagement theory aligned with the literature and themes that unfolded in this qualitative multiple case study's findings. The themes that emerged were in line with the previous studies on strategies used to improve Millennials' engagement; therefore, the themes that emerged from participant interviews were strategies used to engage Millennials in the workplace.

\section{Emergent Theme 1: Coaching Through Education}

The first themes that emerged were coaching, mentoring, and education as strategies used to improve employee engagement among Millennial workers. These themes aligned with findings by Flynn and Duesing (2020), who asserted that mentoring programs in the multigenerational workforce forced Millennials to work with older generations, therefore fostering better communication among the different generations. Managers described using coaching and mentoring as strategies to improve employee engagement among Millennial workers. One manager (M1) stated, "You must coach them and lead by example." M1 asserted that Millennial workers should be mentored rather than solely given tasks to complete. Ghosh, Shuck, Cumberland, and D'Mello (2019) found that coaching and mentoring were influential in employee engagement. Leaders who promote coaching and mentoring could potentially create workplace relationships based on meaning and worth. M2 stated that Millennials like to be led by example. An engaged employee works to improve the organization with their time and talents (Schaufeli, Shimazu, Hakanen, Salanova, \& De Witte, 2019). M1 explained by saying, "I set the tone, and they follow my lead and guidance to perform to expectations. I lead by example." A successful coaching and mentoring environment taps into all these areas and allows for productive two-way dialogue.

In addition to mentoring, another theme was the need for managers to provide more clarity when dealing with Millennial workers. Managers can minimize 
the disengagement cycles by contacting employees through communication channels (Moore et al., 2019). Millennials need an explanation of why they must complete a particular task. Sometimes a simple question to the employee, such as "How is your day going?" can allow the manager an opportunity to gauge how engaged or disengaged an employee is. Employee engagement occurs when employees are involved with the organization cognitively, physically, and emotionally (Kahn, 1990). Starting dialogue helps to break down barriers that separate the multiple generations and provides the Millennial employee an opportunity to express themselves and verbalize what they need help with and how they comprehend what is expected of them.

Another strategy was the need to spend time with Millennials to explain the reason and purpose behind a task in detail (Litvin, Goldsmith, \& Pan, 2018). Some leaders may notice the importance of explaining the company's vision and mission to Millennials. When directing Millennials to perform new tasks, a written manual or visual aid could work best to assist in the explanation. M4 stated, "You have to be visual and clear; this way, the Millennials can go back and use the information as a tool of reference as it is easy to follow." M4 added that communication with the older generations is straightforward; you do not have to spend a lot of time explaining how to do a particular task or why the job needs to be completed. In the fast pace of the hospitality industry, employee engagement directly links to the customer experience (Xiong, So, Wu, \& King, 2019). M1 explained that managers must explain other ways to solve problems to Millennials because the manager has been through it before; providing better examples to help Millennials improve what they are doing is key to successful problem resolution. Furthermore, M4 emphasized that with Millennials, the conversation will be a bit more time consuming due to the added "why" piece to the discussion; however, in a fast-paced industry such as the hospitality industry, the conversation needs to be quick to accommodate the guests. M3 explained that Millennials might have an idea of a team concept, but they still look at how the job benefits them individually. Managers must be transparent to allow the Millennial to see the big picture and understand how a task aligns with the overall goals or finished product.

Additionally, Millennials may look at what coworkers are doing and question why someone else gets to do something while they do not have that same opportunity. Millennials have a reputation for their concern regarding particular assigned tasks and avoiding additional responsibilities (Waples \& Brachle, 2020). One participant in this study, M3, asserted that the Millennial generation has a "me" way of thinking and processing information, as opposed to "we" or "us" thought process. M1 added the need to talk and educate the Millennial worker and make them understand that 'I am not just your boss, it is not 'me, me, me,' it is 'us." M1 further asserted that managers must engage the Millennial worker and help them to understand where the manager is coming from so that everyone can get on a "nice even keel." Older generations were not necessarily con- 
cerned with what others were doing; they were only concerned with their tasks and may offer help when their responsibility is completed. M2 notated that the communication between all generations should be the same and consistent. This consistency ensures the transmission of the same message and ensures that no one receives different treatment and that the expectations are the same for everyone. M2 added that Millennials are less receptive when they perceive that they are being reprimanded and not being recognized for progress. M2 stated that leading by example allows managers to set the standard for the work and foster a "we" environment.

\section{Emergent Theme 2: Rewards That Improve Engagement}

The second theme that emerged was the use of incentives, applause, compliments, and recognition as strategies that improve Millennial employee engagement. Leaders may attribute incentives and recognition as effective strategies to improve employee engagement in the workforce (Busse \& Regenberg, 2018; Lewis \& Wescott, 2017; Litvin et al., 2018). Millennial employees want recognition for work; it does not matter whether the work deserved attention (Eisenberger, Rockstuhl, Shoss, Wen, \& Dulebohn, 2019). M5 stated the following regarding workplace recognition with Millennials.

You have to applaud the Millennial worker when they do something right or without any direction ... if you had an issue with the way they were dressed the day before, but today they corrected the behavior after you spoke to them yesterday, you must recognize the fixed behavior.

Managers in the hospitality industry may consider celebrating the Millennial worker to encourage good behavior to positively recognize behavior and avoid alienating the Millennial worker (Litvin et al., 2018). One manager emphasized that paying a Millennial a compliment such as, "You look nice today," is acknowledging that the Millennial employee took the time to iron their clothes. The fact that a manager showed appreciation for the new effort makes the Millennial employee feel good and reinforces the positive behavior.

In addition, the use of incentives and recognition emerged as a way to improve engagement among Millennials. Lewis and Wescott (2017) noted that Millennials are the "trophy generation" and need a positive message when engaging with employers to maintain productivity. M5 instituted a reward program to provide Millennials with rewards for positive behavior in the form of gift cards to their favorite restaurants or merchants. M5 added "the gift cards range between $\$ 5$ and $\$ 10$, with the $\$ 10$ reward given for above and beyond work." Employees, particularly Millennials, are recognized with a higher amount of gift card if a guest gives them praise. Additionally, the employee's name is entered into an employee of the month and year contest. Most of the study participants stated that giving Millennials the excitement of positive response helps Millennials be more engaged and work harder to treat guests better.

Emergent Theme 3: Enhancing Engagement through Motivation 
The third theme that emerged was Millennials' lack of interest or motivation as a barrier to implementing strategies for enhancing Millennial employee engagement. Motivation is a key component of engagement (Delaney \& Royal, 2017; Singh, 2016). Moreover, the extent of employees' motivation to do more than is required is a top predictor of overall engagement (Delaney \& Royal, 2017; Singh, 2016). Four out of five of the participants stated the lack of interest or lack of motivation among Millennials was a barrier to engagement in the workplace. According to M4, "Millennials feel entitled as if they do not need to do the work and that someone owes them something." Kahn (1990) asserted that employees who view their tasks as meaningful justify their commitment to the organization. M3 included, "The barriers that managers face are that Millennials are not responsive when managers do not accept their lack of motivation or work ethic." Participant M4 emphasized that Millennials' non-responsiveness, lack of motivation, lack of interest, and entitlement are barriers to Millennial engagement in the workplace. Millennials believe that they should automatically ascend to a leadership role as soon as they get hired. Additionally, managers can face barriers when Millennials feel that management is not being transparent. The perception of no transparency can cause Millennials to be unresponsive, unmotivated, and display a lack of interest.

Another theme is the lack of support from upper-level management as a barrier to implementing strategies for enhancing Millennial employee engagement. Singh (2016) asserted that effective employee engagement is based on the company's interpretation of employees that do more than is required. M5 found that managers who treat Millennial workers like family can use tone or body language to improve outcomes when something does not meet the standard. The calmer tone or body language technique allows the Millennial workers to receive the feedback better and retain the message. Communication, teamwork, and collaboration are critical points to any successful organization (Jones \& Thoma, 2019). Participant M2 asserted that management must receive support from upper management and hospitality ownership when it comes to implementing new ideas. Managers who invest in motivation can potentially yield the highest return on overall engagement while maximizing utility (Dyck, Lins, Roth, \& Wagner, 2019).

Emergent Theme 4: Communication Enhances Awareness and Receptiveness

The fourth theme that emerged was awareness, documentation, and receptiveness as ways to address the key barriers to implementing successful strategies for increasing Millennial employees' engagement. Communication can be tailored to the Millennial lifestyle to create a friendly and familiar environment for Millennials to feel they are part of the team (Merriman, Sen, Felo, \& Litzky, 2016). Managers must understand what they are saying, who they are saying it to, and how they deliver the message. M3 affirmed that honest and direct communication is an essential tool for breaking down barriers. On the flip side, do- 
cumentation is a great asset to notate and recap the conversation for future reference. M3 added that the older generation interprets repeating the conversation back to the manager as a lack of comprehension. Managers use documentation to ensure that everyone is on the same page and clearly understands the expectations and goals. Furthermore, communication allows the manager to relay to the Millennial worker that the manager understands them and wants to assist them in reaching their goals. In contrast, the older generation is offended when asked to repeat a conversation with a manager.

Managers must be careful with perceptions when interacting with Millennial employees. M3 noted that managers must be aware of the workplace surroundings, tone, and inflection when relaying information to Millennial workers, as these factors influence whether the Millennial employee understood the information. Tone and inflection help break down the stereotype that individuals who are asked to come to the general manager's office should expect an adverse meeting regarding work performance or some other negative action that needs addressing or correction. M4 asserted that older generations might need to change how they approach engagement strategies because Millennials will take over the workforce in the next few years. M4 further stated that managers would become "dinosaurs" if they do not recognize that the workforce is shifting; change within the workplace is imminent. Participant M5 addressed how older generations can change to adapt to the Millennial workforce.

Millennials are the growing workforce, and we have to understand them and make them feel a part of and include them. We have to be not as strict as we once were and have more patience than what we would usually tolerate.

The findings of this study aligned with Kahn's (1990) employee engagement theory. The study participants addressed the drivers and barriers of employee engagement regarding engaging Millennial employees. The findings of this study support the engagement theory and noteworthy strategies were discussed in the emerging themes. The response from participants indicated the role of leadership as a potential driver in fostering employee engagement. Participants for this study incorporated the following strategies to engage their Millennial workforce: 1) coaching through education, 2) rewards that improve engagement, 3) enhancing engagement through motivation, and 4) communication enhances awareness and receptiveness. Kahn (1990) provided the basis for these findings by yielding an understanding of factors that prevent employee engagement from occurring. The barriers for incorporating engagement strategies noted in this study included lack of interest, lack of motivation and support, and lack of awareness, documentation, and receptiveness.

The themes of this study can be used to understand the importance of improving productivity and Millennial employee engagement by incorporating strategies involving incentives, communication, and mentoring and coaching. 
The five managers I interviewed expressed the importance of communication between managers and Millennials and each group's need to understand one another. Employee engagement theory provides a method to reach organizational goals, close the barrier of disengaged employees, and improve Millennial employee engagement levels. An engaged employee works to improve the organization with their time and talents. Managers' abilities to develop and implement employee engagement initiatives will encourage Millennials to be more productive and stay with the organization longer (Book, Gatling, \& Kim, 2019). Managers can use employee engagement theory to understand the best engagement strategies better and apply them to understand and solve the barrier of disengaged Millennial employees in the hospitality industry.

\section{Applications to Professional Practice}

The purpose of this qualitative multiple case study was to explore the strategies that some hospitality leaders use to improve Millennial employee engagement. Increased Millennial employee engagement is vital for the hospitality industry's overall strength and sustainability and determines productivity levels within various organizations (Datta \& Singh, 2018). As asserted by M2, Millennials should understand that advancement in the industry involves a progression, and hard work should further Millennials' careers in the hospitality industry. The generational disparity could continue to occur as a direct product of the workforce configuration as different generations continue to embody the modern-day workforce (Lyons \& Schweitzer, 2017). Managers who understand Millennial employee engagement will have the ability to implement appropriate leadership initiatives to increase engagement, performance, retention, and Millennial performance (Naim \& Lenka, 2018).

Four themes emerged based on the interview responses and the analysis of the central research question. The main themes included 1) coaching through education, 2) rewards that improve engagement, 3) enhancing engagement through motivation, and 4) communication enhances awareness and receptiveness. The interview responses provided an understanding of both strategies and barriers that affect workforce engagement and employee perceptions in the workplace. Hotel managers who effectively and consistently provide an improved quality customer experience may increase profits and decrease Millennial employee turnover (Kandampully, Zhang, \& Jaakkola, 2018). The participating managers all recognized and agreed that effectively engaging Millennials in the hospitality industry would set some hotels apart by providing a better customer service experience.

These findings apply to business practices, as these themes could be applied to other businesses as strategies managers can use to engage their Millennial workers effectively. In this study, managers emphasized that communication is the most vital tool to breaking down barriers with Millennial workers; therefore, other practices could foster effective communication strategies in the workplace 
and further engage Millennial workers. As recommended by M3, managers could adopt visuals to enhance communication, show what the results from performing a task look like, and explain what they plan to achieve with completing the task. Other managers could be straightforward and reinforce to Millennials that they are an essential part of the organization's overall success. These revelations are essential to developing healthy and robust business practices and strengthening effective communication between managers and their Millennial workers.

Study participants used specific strategies to foster a healthy work environment, increase innovation, and strengthen teamwork. Due to the increased competition from other hotels and alternative lodging accommodations such as Airbnb, hotels should use alternate ways and creative methods to continue improving strategies to engage Millennials (Apte \& Davis, 2019). As M5 suggested, managers could implement the use of incentives and recognition to engage Millennial workers. Millennial workers who feel that they are part of the hotel's success may feel encouraged to perform quality work and complete work assignments with pride, dedication, and speed. The increased knowledge of strategies to engage Millennials could enable managers to retain Millennials longer and close organizational gaps in communication, strengthening customer service and business practices (Woods, 2016). Effective engagement strategies are the determining factor of excellent customer service and financial success in the hospitality industry.

\section{Main Contributions}

Hotel managers who stay up to date with shared innovative engagement strategies and provide managers and Millennials the necessary training aids can demonstrate practical initiatives to impact social change, motivate workers, and decrease Millennial turnover. Unmotivated Millennial workers can have adverse effects on an organization (Eisenberger et al., 2019), contributing to higher unemployment rates if the Millennial employee feels unappreciated. Employee engagement strategies can affect the sustainability of an organization (Al Mehrzi \& Singh, 2016). An organization can increase productivity among its workers by understanding the barriers that prevent employee engagement. In addition, providing incentives to Millennial workers can create a positive work environment among managers who understand Millennial employee engagement. Managers who understand effective communication strategies can help create a positive working relationship between themselves and the Millennial worker and ultimately create a healthier organization and better customer experience. Finally, employee engagement strategies could improve the societal workforce, reduce unemployment rates, and increase the US economy.

\section{Recommendations for Action}

Most organizations thrive after improving Millennial employee engagement. 
Improved Millennial employee engagement increases Millennial employee productivity and enhances customer service. The strategies that the study participants shared could prove beneficial to any organization that employs a combination of multiple generations in the workforce.

My recommendations for action include sharing the participants' years of experience shown through their successful initiatives to increase Millennial employee engagement. The first strategy includes introducing innovative training initiatives to keep Millennials involved and engaged; these initiatives could potentially help organizations retain talented Millennial employees and increase the customer experience for the organization. A second strategy is to implement 2-way communication between the Millennial employee and the manager. Millennials are more productive when included in the decision-making process and given a thorough explanation of work processes. Another strategy for managers to implement is to provide Millennial employees opportunities to advance their careers and involve Millennials in the organization's innovative initiatives. This strategy shows the Millennial employee that the organization is investing in them and confirms that the Millennial employee has a voice.

Managers who implement mentorship programs where the older generation employees can work one-on-one with Millennial employees will allow both generations to understand each other better and give the Millennial employee the inclusion opportunity they seek. Organizations can look for innovative ideas from their Millennial workers to identify Millennial's motivational needs and identify what motivational initiatives management can integrate. Listening to ideas from within the organization can be very beneficial, and managers must tap into internal knowledge and resources.

Another initiative is to engage in off-site and non-work related activities that require engagement through communication and teamwork. Activities such as laser tag, team bowling, and even escape rooms are great ways for managers to think outside the box and foster more camaraderie among their older generations and their Millennial workers. The strategies and initiatives from this study may be of great interest to managers in the hospitality industry because Millennials are the fastest growing workforce.

\section{Recommendations for Further Research}

The recommendations for further research combine the exploration of other business sectors, such as the public sector versus the private sector. The limitation in this study included the reluctance of managers who do not provide the strategies they use to improve Millennial employee engagement. Future researchers may ask Millennial workers what strategies work best to improve Millennial engagement in the workplace. Furthermore, I recommend the research expand beyond the geographic area of this study. The focus of my study was eastern Virginia. The inclusion of other southern states may provide more information on strategies to engage Millennial workers. 
I recommend increasing the sample size and inviting other hotel chains to gather additional strategies to increase Millennial employee engagement. I recommend a more in-depth inquiry of the participants' backgrounds-such as their education, length of time in the industry, and previous management experience-as an individual's background could play a factor in their responses to the questions and their approach to engaging multiple generations in the workforce.

I would recommend including Millennial managers, as Millennial managers could provide different views as they reflect on their experiences while responding to the survey questions. Expanding on ways to improve Millennial engagement in the workforce can prove beneficial to organizations, as it will help organizations engage their growing Millennial workforce and the ever increasing Millennial consumer base that will patronize their businesses. Finally, I recommend representation from participants with a minimum of 10 years in management. Individuals with more years in management may bring various strategies to engage a multigenerational workforce and may have written the corporate policy on how to engage a multigenerational workforce (Chawla, Dokadia, \& Rai, 2017).

\section{Conclusion}

The purpose of this qualitative multiple case study was to explore practical and useful strategies hotel leaders can use to engage Millennial employees. Managers who engage the Millennial workforce could benefit any organization by ensuring that Millennials employees are included in organizational decisions, properly trained, and communicated using innovative techniques. Productivity and customer satisfaction could increase as different generations understand each other and feel essential within the organization.

Organizational leaders may consider facilitating training for managers to learn more about communicating and motivating the Millennial employee. Employee engagement usually occurs when individuals better understand their organization's challenges and know how to address and correct them. The workforce consists of multiple generations; therefore, organizations can benefit from providing employees with ways to communicate, motivate, and express work expectations without excluding a portion of the workforce. Managers should engage in open, honest, and encouraging communication with Millennial employees. Managers who listen to employees and encourage them to express themselves authentically promote healthy relationships and productive workplaces.

Organizational leaders may consider team-building activities in individual departments and company-wide. Team-building activities are great mediums for Millennial employees and managers to strengthen relationships within departments and throughout the organization. Leaders use team-building skills to introduce Millennial talents that may not have been noticed before, therefore allowing the Millennial worker an opportunity to display those talents. Managers 
can separate which strategies work best in different environments and decide on the most useful approaches to engage their Millennial workers.

The strategies discussed within this study may serve as a framework for hospitality leaders to engage their Millennial workers. Hospitality leaders can expound upon these strategies to implement innovative programs to effectively engage Millennials, increasing Millennials' productivity and bettering customer service experiences. Organizations that adopt an innovative approach to Millennial employee engagement will strengthen their workforce by retaining and attracting talented Millennial employees and potentially impacting organizational growth and profitability.

\section{Conflicts of Interest}

The author declares no conflicts of interest regarding the publication of this paper.

\section{References}

Al Mehrzi, N., \& Singh, S. K. (2016). Competing through Employee Engagement: A Proposed Framework. International Journal of Productivity and Performance Management, 65, 831-843. https://doi.org/10.1108/IJPPM-02-2016-0037

Amankwaa, L. (2016). Creating Protocols for Trustworthiness in Qualitative Research. Journal of Cultural Diversity, 23, 121-127. http://www.tuckerpub.com/jcd.htm

Anderson, E., Buchko, A. A., \& Buchko, K. J. (2016). Giving Negative Feedback to Millennials. Management Research Review, 39, 692-705.

https://doi.org/10.1108/MRR-05-2015-0118

Anitha, J. (2014). Determinants of Employee Engagement and Their Impact on Employee Performance. International Journal of Productivity and Performance Management, 63, 308-323. https://doi.org/10.1108/IJPPM-01-2013-0008

Apte, U. M., \& Davis, M. M. (2019). Sharing Economy Services: Business Model Generation. California Management Review, 61, 104-131. https://doi.org/10.1177/0008125619826025

Argote, L., \& Guo, J. M. (2016). Routines and Transactive Memory Systems: Creating, Coordinating, Retaining, and Transferring Knowledge in Organizations. Research in Organizational Behavior, 36, 65-84. https://doi.org/10.1016/j.riob.2016.10.002

Armstrong, L., \& Rimes, K. A. (2016). Mindfulness-Based Cognitive Therapy for Neuroticism (Stress Vulnerability): A Pilot Randomized Study. Behavior Therapy, 47, 287-298. https://doi.org/10.1016/j.beth.2015.12.005

Bailey, J. (2008). First Steps in Qualitative Data Analysis: Transcribing. Family Practice, 25, 127-131. https://doi.org/10.1093/fampra/cmn003

Bal, P. M., \& De Lange, A. H. (2015). From Flexibility Human Resource Management to Employee Engagement and Perceived Job Performance across the Lifespan: A Multisample Study. Journal of Occupational and Organizational Psychology, 88, 126-154. https://doi.org/10.1111/joop.12082

Bandara, W., Furtmueller, E., Gorbacheva, E., Miskon, S., \& Beekhuyzen, J. (2015). Achieving Rigor in Literature Reviews: Insights from Qualitative Data Analysis and Tool-Support. Communications of the Association for Information Systems, 37, 154-204. https://doi.org/10.17705/1CAIS.03708 
Bannon, S., Ford, K., \& Meltzer, L. (2011). Understanding Millennials in the Workplace. CPA Journal, 81, 61-65. https://www.cpajournal.com/

Barbour, R. (2013). Introducing Qualitative Research: A Student's Guide. Thousand Oaks, CA: Sage. https://doi.org/10.4135/9781526485045

Barry, M., \& Wilkinson, A. (2016). Pro-Social or Pro-Management? A Critique of the Conception of Employee Voice as a Pro-Social Behaviour within Organizational Behaviour. British Journal of Industrial Relations, 54, 261-284.

https://doi.org/10.1111/bjir.12114

Baxter, P., \& Jack, S. (2008). Qualitative Case Study Methodology: Study Design and Implementation for Novice Researchers. Qualitative Report, 13, 544-559.

http://www.nova.edu/ssss/QR/QR13-4/baxter.pdf

Beam, M. A., Child, J. T., Hutchens, M. J., \& Hmielowski, J. D. (2018). Context Collapse and Privacy Management: Diversity in Facebook Friends Increases Online News Reading and Sharing. New Media \& Society, 20, 2296-2314.

https://doi.org/10.1177/1461444817714790

Bell, E., Bryman, A., \& Harley, B. (2018). Business Research Methods. Oxford, England: Oxford University Press.

Bennett, M. M., Beehr, T. A., \& Ivanitskaya, L. V. (2017). Work-Family Conflict: Differences across Generations and Life Cycles. Journal of Managerial Psychology, 32, 314-332. https://doi.org/10.1108/JMP-06-2016-0192

Bernard, H. R. (2017). Research Methods in Anthropology: Qualitative and Quantitative Approaches. Lanham, MD: Rowman \& Littlefield.

Birt, L., Scott, S., Cavers, D., Campbell, C., \& Walter, F. (2016). Member Checking: A Tool to Enhance Trustworthiness or Merely a Nod to Validation? Qualitative Health Research, 26, 1802-1811. https://doi.org/10.1177/1049732316654870

Blal, I., Singal, M., \& Templin, J. (2018). Airbnb's Effect on Hotel Sales Growth. International Journal of Hospitality Management, 73, 85-92. https://doi.org/10.1016/j.ijhm.2018.02.006

Bloomberg, L. D., \& Volpe, M. F. (2012). Completing Your Qualitative Dissertation: A Road Map from Beginning to End (2nd ed.). Thousand Oaks, CA: Sage.

Bolino, M. C., \& Grant, A. M. (2016). The Bright Side of Being Prosocial at Work, and the Dark Side, Too: A Review and Agenda for Research on Other-Oriented Motives, Behavior, and Impact in Organizations. Academy of Management Annals, 10, 599-670. https://doi.org/10.5465/19416520.2016.1153260

Bolino, M. C., Hsiung, H. H., Harvey, J., \& LePine, J. A. (2015). “Well, I'm tired of Tryin' !" Organizational Citizenship Behavior and Citizenship Fatigue. Journal of Applied Psychology, 100, 56-74. https://doi.org/10.1037/a0037583

Bolino, M. C., Klotz, A. C., \& Turnley, W. H. (2016). The Unintended Consequences of Organizational Citizenship Behaviors for Employees, Teams, and Organizations. In P. M. Podsakoff, S. B. Mackenzie, \& N. P. Podsakoff (Eds.), The Oxford Handbook of Organizational Citizenship Behavior. Oxford: Oxford University Press. https://doi.org/10.1093/oxfordhb/9780190219000.013.11

Book, L., Gatling, A., \& Kim, J. (2019). The Effects of Leadership Satisfaction on Employee Engagement, Loyalty, and Retention in the Hospitality Industry. Journal of Human Resources in Hospitality \& Tourism, 18, 368-393. https://doi.org/10.1080/15332845.2019.1599787

Börsch-Supan, A., \& Weiss, M. (2016). Productivity and Age: Evidence from Work 
Teams at the Assembly Line. Journal of the Economics of Ageing, 7, 30-42. https://doi.org/10.1016/j.jeoa.2015.12.001

Bowling, N. A., Khazon, S., Meyer, R. D., \& Burrus, C. J. (2015). Situational Strength as a Moderator of the Relationship between Job Satisfaction and Job Performance: A Meta-Analytic Examination. Journal of Business and Psychology, 30, 89-104. https://doi.org/10.1007/s10869-013-9340-7

Brooks, S., \& Califf, C. (2017). Social Media-Induced Technostress: Its Impact on the Job Performance of It Professionals and the Moderating Role of Job Characteristics. Computer Networks, 114, 143-153. https://doi.org/10.1016/j.comnet.2016.08.020

Busse, R., \& Regenberg, S. (2018). Revisiting the "Authoritarian versus Participative" Leadership Style Legacy: A New Model of the Impact of Leadership Inclusiveness on Employee Engagement. Journal of Leadership \& Organizational Studies, 26, 510-525. https://doi.org/10.1177/1548051818810135

Cain, L., Tanford, S., \& Shulga, L. (2018). Customers' Perceptions of Employee Engagement: Fortifying the Service-Profit Chain. International Journal of Hospitality \& Tourism Administration, 19, 52-77. https://doi.org/10.1080/15256480.2017.1305312

Caretta, M. A. (2016). Member Checking: A Feminist Participatory Analysis of the Use of Preliminary Results Pamphlets in Cross-Cultural, Cross-Language Research. Qualitative Research, 16, 305-318. https://doi.org/10.1177/1468794115606495

Castillo-Montoya, M. (2016). Preparing for Interview Research: The Interview Protocol Refinement Framework. Qualitative Report, 21, 811-831.

https://nsuworks.nova.edu/tqr/vol21/iss5/2/?utm source=nsuworks.nova.edu $\% 2$ Ftqr\% 2Fvol21\%2Fiss5\%2F2\&utm medium=PDF\&utm campaign=PDFCoverPages

Chawla, D., Dokadia, A., \& Rai, S. (2017). Multigenerational Differences in Career Preferences, Reward Preferences and Work Engagement among Indian Employees. Global Business Review, 18, 181-197. https://doi.org/10.1177/0972150916666964

Cheah, K. K., Foster, F. D., Heaney, R., Higgins, T., Oliver, B., O’Neill, T., \& Russell, R. (2015). Discussions on Long-Term Financial Choice. Australian Journal of Management, 40, 414-434. https://doi.org/10.1177/0312896214532476

Christensen Hughes, J., \& Rog, E. (2008). Talent Management: A Strategy for Improving Employee Recruitment, Retention and Engagement within Hospitality Organizations. International Journal of Contemporary Hospitality Management, 20, 743-757. https://doi.org/10.1108/09596110810899086

Clark, L., Birkhead, A. S., Fernandez, C., \& Egger, M. J. (2017). A Transcription and Translation Protocol for Sensitive Cross-Cultural Team Research. Qualitative Health Research, 27, 1751-1764. https://doi.org/10.1177/1049732317726761

Clarke, V., \& Braun, V. (2013). Teaching Thematic Analysis: Overcoming Challenges and Developing Strategies for Effective Learning. Psychologist, 26, 120-123. https://thepsychologist.bps.org.uk

Colepicolo, E. (2015). Information Reliability for Academic Research: Review and Recommendations. New Library World, 116, 646-660. https://doi.org/10.1108/NLW-05-2015-0040

Constantinou, C. S., Georgiou, M., \& Perdikogianni, M. (2017). A Comparative Method for Themes Saturation (CoMeTS) in Qualitative Interviews. Qualitative Research, 17, 571-588. https://doi.org/10.1177/1468794116686650

Conway, E., Fu, N., Monks, K., Alfes, K., \& Bailey, C. (2016). Demands or Resources? The Relationship between HR Practices, Employee Engagement, and Emotional Exhaustion within a Hybrid Model of Employment Relations. Human Resource Management, 55, 
901-917. https://doi.org/10.1002/hrm.21691

Crosby, B. C., \& Bryson, J. M. (2018). Why Leadership of Public Leadership Research Matters: And What to Do about It. Public Management Review, 20, 1265-1286. https://doi.org/10.1080/14719037.2017.1348731

Crosina, E., \& Pratt, M. G. (2019). Toward a Model of Organizational Mourning: The Case of Former Lehman Brothers Bankers. Academy of Management Journal, 62, 66-98. https://doi.org/10.5465/amj.2017.0140

Cypress, B. S. (2017). Rigor or Reliability and Validity in Qualitative reSearch: Perspectives, Strategies, Reconceptualization, and Recommendations. Dimensions of Critical Care Nursing, 36, 253-263. https://doi.org/10.1097/DCC.0000000000000253

Cyr, J. (2016). The Pitfalls and Promise of Focus Groups as a Data Collection Method. Sociological Methods \& Research, 45, 231-259. https://doi.org/10.1177/0049124115570065

Datta, A., \& Singh, R. (2018). Determining the Dimensions of Organizational Climate Perceived by the Hotel Employees. Journal of Hospitality and Tourism Management, 36, 40-48. https://doi.org/10.1016/j.jhtm.2018.07.001

Davidson, J., Thompson, S., \& Harris, A. (2017). Qualitative Data Analysis Software Practices in Complex Research Teams: Troubling the Assumptions about Transparency and Portability. Qualitative Inquiry, 23, 779-788. https://doi.org/10.1177/1077800417731082

Dechawatanapaisal, D. (2018). Employee Retention: The Effects of Internal Branding and Brand Attitudes in Sales Organizations. Personnel Review, 47, 675-693. https://doi.org/10.1108/PR-06-2017-0193

Delaney, M. L., \& Royal, M. A. (2017). Breaking Engagement Apart: The Role of Intrinsic and Extrinsic Motivation in Engagement Strategies. Industrial and Organizational Psychology, 10, 127-140. https://doi.org/10.1017/iop.2017.2

Denzin, N. K. (2017). The Research Act: A Theoretical Introduction to Sociological Methods. London, England: Routledge. https://doi.org/10.4324/9781315134543

Devotta, K., Woodhall-Melnik, J., Pedersen, C., Wendaferew, A., Dowbor, T. P., Guilcher, S. J., \& Matheson, F. I. (2016). Enriching Qualitative Research by Engaging Peer Interviewers: A Case Study. Qualitative Research, 16, 661-680.

https://doi.org/10.1177/1468794115626244

Dillaway, H., Lysack, C., \& Luborsky, M. R. (2017). Qualitative Approaches to Interpreting and Reporting Data. In R. R. Taylor (Ed.), Kielhofner's Research in Occupational Therapy: Methods of Inquiry for Enhancing Practice (pp. 228-243). Philadelphia, PA: F. A. Davis.

Dumay, J. (2016). A Critical Reflection on the Future of Intellectual Capital: From Reporting to Disclosure. Journal of Intellectual Capital, 17, 168-184. https://doi.org/10.1108/JIC-08-2015-0072

Duxbury, L., \& Ormsbee, F. (2020). Does Studying the Past Help Us Understand the Future? An Examination of the Expectations of Gen X Knowledge Workers. International Journal of Human Resource Management, 31, 935-963. https://doi.org/10.1080/09585192.2017.1393835

Dyck, A., Lins, K. V., Roth, L., \& Wagner, H. F. (2019). Do Institutional Investors Drive Corporate Social Responsibility? International Evidence. Journal of Financial Economics, 131, 693-714. https://doi.org/10.1016/j.jfineco.2018.08.013

Dziewanowska, K., Pearce, A., \& Zupan, N. (2016). Generation Y’s Expectations Regarding Their Future Employment Relationships Poses a Challenge for Their Employers. 
Journal of Human Resource Management, 1, 1-12. https://www.jhrm.eu

Eisenberger, R., Rockstuhl, T., Shoss, M. K., Wen, X., \& Dulebohn, J. (2019). Is the Employee-Organization Relationship Dying or Thriving? A Temporal Meta-Analysis. Journal of Applied Psychology, 104, 1036-1057. https://doi.org/10.1037/apl0000390

Elo, S., Kääriäinen, M., Kanste, O., Pölkki, T., Utriainen, K., \& Kyngäs, H. (2014). Qualitative Content Analysis: A Focus on Trustworthiness. Sage Open, 4, 1-10. https://doi.org/10.1177/2158244014522633

Ertas, N. (2015). Turnover Intentions and Work Motivations of Millennial Employees in Federal Service. Public Personnel Management, 44, 401-423. https://doi.org/10.1177/0091026015588193

Evans III, J. H., Feng, M., Hoffman, V. B., Moser, D. V., \& Van der Stede, W. A. (2015). Points to Consider When Self-Assessing Your Empirical Accounting Research. Contemporary Accounting Research, 32, 1162-1192. https://doi.org/10.1111/1911-3846.12133

Ferri-Reed, J. (2014). Are Millennial Employees Changing How Managers Manage? Journal for Quality and Participation, 37, 15-18.

https://asq.org/quality-resources/pub/journal-for-quality-and-participation

Fink, A. (2015). How to Conduct Surveys: A Step-by-Step Guide. Thousand Oaks, CA: Sage.

Fischer, C. S., Hout, M., Jankowski, M. S., Lucas, S. R., Swidler, A., \& Voss, K. (2018). Inequality by Design. In D. Grusky, \& S. Szelenyi (Eds.), The Inequality Reader (pp. 20-24). London, England: Routledge. https://doi.org/10.4324/9780429494468-3

Fishman, A. A. (2016). How Generational Differences Will Impact America's Aging Workforce: Strategies for Dealing with Aging Millennials, Generation X, and Baby Boomers. Strategic HR Review, 15, 250-257. https://doi.org/10.1108/SHR-08-2016-0068

Flick, U. (2017). Mantras and Myths: The Disenchantment of Mixed-Methods Research and Revisiting Triangulation as a Perspective. Qualitative Inquiry, 23, 46-57. https://doi.org/10.1177/1077800416655827

Flynn, J., \& Duesing, R. J. (2020). Toward Developing an Applied Framework to Help Foster Success in Generational Transition of Family Businesses. Journal of Small Business \& Entrepreneurship, 32, 287-308. https://doi.org/10.1080/08276331.2018.1510695

Ford, R. C., Piccolo, R. F., \& Ford, L. R. (2017). Strategies for Building Effective Virtual teams: Trust Is Key. Business Horizons, 60, 25-34. https://doi.org/10.1016/j.bushor.2016.08.009

Fritz, R. L., \& Vandermause, R. (2018). Data Collection via In-Depth Email Interviewing: Lessons from the Field. Qualitative Health Research, 28, 1640-1649. https://doi.org/10.1177/1049732316689067

Fusch, P. I., \& Ness, L. R. (2015). Are We There Yet? Data Saturation in Qualitative Research. Qualitative Report, 20, 1408-1416.

https://cpb-us-east-1-juc1ugur1qwqqqo4.stackpathdns.com/sites.nova.edu/dist/a/4/file s/2015/09/fusch1.pdf

Gandomani, T. J., Zulzalil, H., Ghani, A. A. A., Sultan, A. B. M., \& Parizi, R. M. (2015). The Impact of Inadequate and Dysfunctional Training on Agile Transformation Process: A Grounded Theory Study. Information and Software Technology, 57, 295-309. https://doi.org/10.1016/j.infsof.2014.05.011

Garbarski, D., Schaeffer, N. C., \& Dykema, J. (2016). Interviewing Practices, Conversational Practices, and Rapport: Responsiveness and Engagement in the Standardized 
Survey Interview. Sociological Methodology, 46, 1-38. https://doi.org/10.1177/0081175016637890

Gentles, S. J., Charles, C., Ploeg, J., \& McKibbon, K. (2015). Sampling in Qualitative Research: Insights from an Overview of the Methods Literature. Qualitative Report, 20, 1772-1789. https://pdfs.semanticscholar.org/3bd0/66b5d7ea4e3a933699576689a855d09f08b6.pdf

Ghosh, R., Shuck, B., Cumberland, D., \& D’Mello, J. (2019). Building Psychological Capital and Employee Engagement: Is Formal Mentoring a Useful Strategic Human Resource Development Intervention? Performance Improvement Quarterly, 32, 37-54. https://doi.org/10.1002/piq.21285

Glazer, S., Mahoney, A. C., \& Randall, Y. (2019). Employee Development's Role in Organizational Commitment: A Preliminary Investigation Comparing Generation X and Millennial Employees. Industrial and Commercial Training, 51, 1-12. https://doi.org/10.1108/ICT-07-2018-0061

Goldberg, A. E., \& Allen, K. R. (2015). Communicating Qualitative Research: Some Practical Guideposts for Scholars. Journal of Marriage and Family, 77, 3-22. https://doi.org/10.1111/jomf.12153

Guest, G., Namey, E., Taylor, J., Eley, N., \& McKenna, K. (2017). Comparing Focus Groups and Individual Interviews: Findings from a Randomized Study. International Journal of Social Research Methodology, 20, 693-708. https://doi.org/10.1080/13645579.2017.1281601

Gurran, N., \& Phibbs, P. (2017). When Tourists Move in: How Should Urban Planners Respond to Airbnb? Journal of the American Planning Association, 83, 80-92. https://doi.org/10.1080/01944363.2016.1249011

Hammarberg, K., Kirkman, M., \& De Lacey, S. (2016). Qualitative Research Methods: When to Use Them and How to Judge Them. Human Reproduction, 31, 498-501. https://doi.org/10.1093/humrep/dev334

Hancock, D. R., \& Algozzine, B. (2016). Doing Case Study Research: A Practical Guide for Beginning Researchers. New York, NY: Teachers College Press.

Hayes, J. B., Parks, C., McNeilly, S., \& Johnson, P. (2018). Boomers to Millennials: Generational Stereotypes at Work in Academic Librarianship. Journal of Academic Librarianship, 44, 845-853. https://doi.org/10.1016/j.acalib.2018.09.011

Heckemann, B., Breimaier, H. E., Halfens, R. J., Schols, J. M., \& Hahn, S. (2016). The Participant's Perspective: Learning from an Aggression Management Training Course for Nurses. Insights from a Qualitative Interview Study. Scandinavian Journal of Caring Sciences, 30, 574-585. https://doi.org/10.1111/scs.12281

Hennink, M. M., Kaiser, B. N., \& Marconi, V. C. (2017). Code Saturation versus Meaning Saturation: How Many Interviews Are Enough? Qualitative Health Research, 27, 591-608. https://doi.org/10.1177/1049732316665344

Hoyle, R. (2017). Learning Strategies for a Changing Workforce. Strategic HR Review, 16, 255-260. https://doi.org/10.1108/SHR-08-2017-0052

Ihantola, E. M., \& Kihn, L. A. (2011). Threats to Validity and Reliability in Mixed Methods Accounting Research. Qualitative Research in Accounting \& Management, 8, 39-58. https://doi.org/10.1108/11766091111124694

James, N. (2016). Using Email Interviews in Qualitative Educational Research: Creating Space to Think and Time to Talk. International Journal of Qualitative Studies in Education, 29, 150-163. https://doi.org/10.1080/09518398.2015.1017848

Jaskiewicz, P., Combs, J. G., \& Rau, S. B. (2015). Entrepreneurial Legacy: Toward a 
Theory of How Some Family Firms Nurture Transgenerational Entrepreneurship. Journal of Business Venturing, 30, 29-49. https://doi.org/10.1016/j.jbusvent.2014.07.001

Jassawalla, A., \& Sashittal, H. (2017). How and Why Millennials Are Initiating Conflict in Vertical Dyads and What They Are Learning: A Two-Stage Study. International Journal of Conflict Management, 28, 644-670. https://doi.org/10.1108/IJCMA-05-2016-0026

Jensen, M. C. (2017). Value Maximisation, Stakeholder Theory and the Corporate Objective Function. In J. Andriof, S. Waddock, B. Husted, \& S. S. Rahman (Eds.), Unfolding Stakeholder Thinking (pp. 65-84). London, England: Routledge. https://doi.org/10.4324/9781351281881-4

Jin, M. H., \& McDonald, B. (2017). Understanding Employee Engagement in the Public Sector: The Role of Immediate Supervisor, Perceived Organizational Support, and Learning Opportunities. American Review of Public Administration, 47, 881-897. https://doi.org/10.1177/0275074016643817

Jones, A., \& Thoma, V. (2019). Determinants for Successful Agile Collaboration between UX Designers and Software Developers in a Complex Organisation. International Journal of Human-Computer Interaction, 35, 1914-1935. https://doi.org/10.1080/10447318.2019.1587856

Joslin, R., \& Müller, R. (2016). Identifying Interesting Project Phenomena Using Philosophical and Methodological Triangulation. International Journal of Project Management, 34, 1043-1056. https://doi.org/10.1016/j.ijproman.2016.05.005

Kahn, W. A. (1990). Psychological Conditions of Personal Engagement and Engagement at Work. Academy of Management Journal, 33, 692-724. https://doi.org/10.5465/256287

Kandampully, J., Zhang, T., \& Jaakkola, E. (2018). Customer Experience Management in Hospitality: A Literature Synthesis, New Understanding and Research Agenda. International Journal of Contemporary Hospitality Management, 30, 21-56. https://doi.org/10.1108/IJCHM-10-2015-0549

Kang, M., \& Sung, M. (2017). How Symmetrical Employee Communication Leads to Employee Engagement and Positive Employee Communication Behaviors: The Mediation of Employee-Organization Relationships. Journal of Communication Management, 21, 82-102. https://doi.org/10.1108/JCOM-04-2016-0026

Karatepe, O. M. (2013). High-Performance Work Practices and Hotel Employee Performance: The Mediation of Work Engagement. International Journal of Hospitality Management, 32, 132-140. https://doi.org/10.1016/j.ijhm.2012.05.003

Kern, F. G. (2018). The Trials and Tribulations of Applied Triangulation: Weighing Different Data Sources. Journal of Mixed Methods Research, 12, 166-181. https://doi.org/10.1177/1558689816651032

Key, T. M., \& Czaplewski, A. J. (2017). Upstream Social Marketing Strategy: An Integrated Marketing Communications Approach. Business Horizons, 60, 325-333. https://www.journals.elsevier.com/business-horizons https://doi.org/10.1016/j.bushor.2017.01.006

Kim, M., Knutson, B. J., \& Choi, L. (2016). The Effects of Employee Voice and Delight on Job Satisfaction and Behaviors: Comparison between Employee Generations. Journal of Hospitality Marketing \& Management, 25, 563-588. https://doi.org/10.1080/19368623.2015.1067665

Koelsch, L. E. (2013). Reconceptualizing the Member Check Interview. International 
Journal of Qualitative Methods, 12, 168-179.

https://doi.org/10.1177/160940691301200105

Kolar, K., Ahmad, F., Chan, L., \& Erickson, P. G. (2015). Timeline Mapping in Qualitative Interviews: A Study of Resilience with Marginalized Groups. International Journal of Qualitative Methods, 14, 13-32. https://doi.org/10.1177/160940691501400302

Koro-Ljungberg, M. (2015). Reconceptualizing Qualitative Research: Methodologies without Methodology. Thousand Oaks, CA: Sage. https://doi.org/10.4135/9781071802793

Krause, L., Herbst-Irmer, R., Sheldrick, G. M., \& Stalke, D. (2015). Comparison of Silver and Molybdenum Microfocus X-Ray Sources for Single-Crystal Structure Determination. Journal of Applied Crystallography, 48, 3-10.

https://doi.org/10.1107/S1600576714022985

Krishnaveni, R., \& Monica, R. (2016). Identifying the Drivers for Developing and Sustaining Engagement among Employees. IUP Journal of Organizational Behavior, 15, 7-15. https://www.iupindia.in/405/ijob.asp

Kuron, L. K., Lyons, S. T., Schweitzer, L., \& Ng, E. S. (2015). Millennials' Work Values: Differences across the School to Work Transition. Personnel Review, 44, 991-1009.

https://doi.org/10.1108/PR-01-2014-0024

Lamb, M. E., Orbach, Y., Hershkowitz, I., Esplin, P. W., \& Horowitz, D. (2007). Structured Forensic Interview Protocol Improve the Quality and Informativeness of Investigative Interviews with Children: A Review of Research Using the NICHD Investigative Interview Protocol. Child Abuse \& Neglect, 31, 1201-1231.

https://doi.org/10.1016/j.chiabu.2007.03.021

Lapadat, J. C., \& Lindsay, A. C. (1999). Transcription in Research and Practice: From Standardization of Technique to Interpretive Positionings. Qualitative Inquiry, 5, 64-86. https://doi.org/10.1177/107780049900500104

Lehnert, K., Craft, J., Singh, N., \& Park, Y. H. (2016). The Human Experience of Ethics: A Review of a Decade of Qualitative Ethical Decision-Making Research. Business Ethics, 25, 498-537. https://doi.org/10.1111/beer.12129

Lewis, L. F., \& Wescott, H. D. (2017). Multi-Generational Workforce: Four Generations United in Lean. Journal of Business Studies Quarterly, 8, 1-14.

http://www.jbsq.org/?i=1

Lim, S. S. (2016). Young People and Communication Technologies: Emerging Challenges in Generational Analysis. In J. Nussbaum (Ed.), Communication across the Life Span (pp. 5-19). Bern, Switzerland: Peter Lang.

Litvin, S. W., Goldsmith, R. E., \& Pan, B. (2018). A Retrospective View of Electronic Word-of-Mouth in Hospitality and Tourism Management. International Journal of Contemporary Hospitality Management, 30, 313-325. https://doi.org/10.1108/IJCHM-08-2016-0461

Lyons, S. T., \& Schweitzer, L. (2017). A Qualitative Exploration of Generational Identity: Making Sense of Young and Old in the Context of Today's Workplace. Work, Aging and Retirement, 3, 209-224. https://doi.org/10.1093/workar/waw024

Lyons, S., \& Kuron, L. (2014). Generational Differences in the Workplace: A Review of the Evidence and Directions for Future Research. Journal of Organizational Behavior, 35, S139-S157. https://doi.org/10.1002/job.1913

Malterud, K., Siersma, V. D., \& Guassora, A. D. (2016). Sample Size in Qualitative Interview Studies: Guided by Information Power. Qualitative Health Research, 26, 1753-1760.

https://doi.org/10.1177/1049732315617444 
Marshall, C., \& Rossman, G. B. (2016). Designing Qualitative Research (6th ed.). Thousand Oaks, CA: Sage.

McGinnis Johnson, J., \& Ng, E. S. (2016). Money Talks or Millennials Walk: The Effect of Compensation on Nonprofit Millennial Workers Sector-Switching Intentions. Review of Public Personnel Administration, 36, 283-305. https://doi.org/10.1177/0734371X15587980

McIntosh, M. J., \& Morse, J. M. (2015). Situating and Constructing Diversity in Semi-Structured Interviews. Global Qualitative Nursing Research, 2. https://doi.org/10.1177/2333393615597674

Meng, J., Reber, B. H., \& Rogers, H. (2017). Managing Millennial Communication Professionals: Connecting Generation Attributes, Leadership Development, and Employee Engagement. Acta Prosperitatis, 8, 68-83. http://www.turiba.lv

Menges, J. I., Tussing, D. V., Wihler, A., \& Grant, A. M. (2017). When Job Performance Is All Relative: How Family Motivation Energizes Effort and Compensates for Intrinsic Motivation. Academy of Management Journal, 60, 695-719. https://doi.org/10.5465/amj.2014.0898

Menguc, B., Auh, S., Yeniaras, V., \& Katsikeas, C. S. (2017). The Role of Climate: Implications for Service Employee Engagement and Customer Service Performance. Journal of the Academy of Marketing Science, 45, 428-451. https://doi.org/10.1007/s11747-017-0526-9

Merriam, S. B., \& Tisdell, E. J. (2015). Qualitative Research: A Guide to Design and Implementation. Hoboken, NJ: John Wiley \& Sons.

Merriman, K., Sen, S., Felo, A., \& Litzky, B. (2016). Employees and Sustainability: The Role of Incentives. Journal of Managerial Psychology, 31, 820-836. https://doi.org/10.1108/JMP-09-2014-0285

Methot, J. R., Lepine, J. A., Podsakoff, N. P., \& Christian, J. S. (2016). Are Workplace Friendships a Mixed Blessing? Exploring Tradeoffs of Multiplex Relationships and Their Associations with Job Performance. Personnel Psychology, 69, 311-355. https://doi.org/10.1111/peps.12109

Milligan, R. S. (2016). Conflict and Diversity Associated with Four Generations in the Workforce. Doctoral Dissertation, Walden University, Minneapolis, MN.

Milliken, F. J., Schipani, C. A., Bishara, N. D., \& Prado, A. M. (2015). Linking Workplace Practices to Community Engagement: The Case for Encouraging Employee Voice. Academy of Management Perspectives, 29, 405-421. https://doi.org/10.5465/amp.2013.0121

Mishra, K., Boynton, L., \& Mishra, A. (2014). Driving Employee Engagement: The Expanded Role of Internal Communications. International Journal of Business Communication, 51, 183-202. https://doi.org/10.1177/2329488414525399

Moore, C., Mayer, D. M., Chiang, F. F., Crossley, C., Karlesky, M. J., \& Birtch, T. A. (2019). Leaders Matter Morally: The Role of Ethical Leadership in Shaping Employee Moral Cognition and Misconduct. Journal of Applied Psychology, 104, 123-145. https://doi.org/10.1037/apl0000341

Morse, J. M. (2015). Critical Analysis of Strategies for Determining Rigor in Qualitative Inquiry. Qualitative Health Research, 25, 1212-1222. https://doi.org/10.1177/1049732315588501

Moser, A., \& Korstjens, I. (2018). Series: Practical Guidance to Qualitative Research. Part 3: Sampling, Data Collection and Analysis. European Journal of General Practice, 24, 9-18. https://doi.org/10.1080/13814788.2017.1375091 
Naim, M. F., \& Lenka, U. (2018). Development and Retention of Generation Y Employees: A Conceptual Framework. Employee Relations, 40, 433-455. https://doi.org/10.1108/ER-09-2016-0172

Namey, E., Guest, G., McKenna, K., \& Chen, M. (2016). Evaluating Bang for the Buck: A Cost-Effectiveness Comparison between Individual Interviews and Focus Groups Based on Thematic Saturation Levels. American Journal of Evaluation, 37, 425-440. https://doi.org/10.1177/1098214016630406

Newell, S. J., \& Goldsmith, R. E. (2001). The Development of a Scale to Measure Perceived Corporate Credibility. Journal of Business Research, 52, 235-247. https://doi.org/10.1016/S0148-2963(99)00104-6

Nolan, L. S. (2015). The Roar of Millennials: Retaining Top Talent in the Workplace. Journal of Leadership, Accountability and Ethics, 12, 69-75. http://na-businesspress.homestead.com/JLAE/NolanLS Web12 5 .pdf

O’Connor, A., \& Raile, A. N. (2015). Millennials “Get a 'Real Job' ": Exploring Generational Shifts in the Colloquialism's Characteristics and Meanings. Management Communication Quarterly, 29, 276-290. https://doi.org/10.1177/0893318915580153

Onwuegbuzie, A. J., \& Leech, N. L. (2007). Validity and Qualitative Research: An Oxymoron? Quality \& Quantity, 41, 233-249. https://doi.org/10.1007/s11135-006-9000-3

Padgett, D. K. (2017). Qualitative Methods in Social Work Research (2nd ed.). Thousand Oaks, CA: Sage.

Peters, K., \& Halcomb, E. (2015). Interviews in Qualitative Research. Nurse Researcher, 22, 6-7. https://doi.org/10.7748/nr.22.4.6.s2

Petr, C., Belk, R., \& Decrop, A. (2015). Videography in Marketing Research: Mixing Art and Science. Arts and the Market, 5, 73-102. https://doi.org/10.1108/AM-01-2014-0002

Pucciarelli, F., \& Kaplan, A. (2016). Competition and Strategy in Higher Education: Managing Complexity and Uncertainty. Business Horizons, 59, 311-320.

https://doi.org/10.1016/j.bushor.2016.01.003

Putra, E. D., Cho, S., \& Liu, J. (2017). Extrinsic and Intrinsic Motivation on Work Engagement in the Hospitality Industry: Test of Motivation Crowding Theory. Tourism and Hospitality Research, 17, 228-241. https://doi.org/10.1177/1467358415613393

Rabiee, F. (2004). Focus-Group Interview and Data Analysis. Proceedings of the Nutrition Society, 63, 655-660. https://doi.org/10.1079/PNS2004399

Raghuram, S., Gajendran, R. S., Liu, X., \& Somaya, D. (2017). Boundaryless LMX: Examining LMX's Impact on External Career Outcomes and Alumni Goodwill. Personnel Psychology, 70, 399-428. https://doi.org/10.1111/peps.12143

Ranney, M. L., Meisel, Z. F., Choo, E. K., Garro, A. C., Sasson, C., \& Morrow Guthrie, K. (2015). Interview-Based Qualitative Research in Emergency Care Part II: Data Collection, Analysis and Results Reporting. Academic Emergency Medicine, 22, 1103-1112. https://doi.org/10.1111/acem.12735

Raza, S., Ansari, N., Humayon, D. A. A., Hussain, M. S., \& Aziz, K. (2017). Factors Affecting Millennials Employee Engagement in Government Sector. International Journal of Management Excellence, 10, 1195-1200. https://doi.org/10.17722/ijme.v10i1.947

Rich, B. L., Lepine, J. A., \& Crawford, E. R. (2010). Job Engagement: Antecedents and Effects on Job Performance. Academy of Management Journal, 53, 617-635. https://doi.org/10.5465/amj.2010.51468988

Richardson, K. M. (2017). Managing Employee Stress and Wellness in the New Millennium. Journal of Occupational Health Psychology, 22, 423-428. 
https://doi.org/10.1037/ocp0000066

Riege, A. M. (2003). Validity and Reliability Tests in Case Study Research: A Literature Review with "Hands-On" Applications for Each Research Phase. Qualitative Market Research, 6, 75-86. https://doi.org/10.1108/13522750310470055

Risman, B. J. (2017). 2016 Southern Sociological Society Presidential Address: Are Millennials Cracking the Gender Structure? Social Currents, 4, 208-227. https://doi.org/10.1177/2329496517697145

Robinson, O. C. (2014). Sampling in Interview-Based Qualitative Research: A Theoretical and Practical Guide. Qualitative Research in Psychology, 11, 25-41.

https://doi.org/10.1080/14780887.2013.801543

Rosenthal, M. (2016). Qualitative Research Methods: Why, When, and How to Conduct Interviews and Focus Groups in Pharmacy Research. Currents in Pharmacy Teaching and Learning, 8, 509-516. https://doi.org/10.1016/j.cptl.2016.03.021

Rowley, J. (2012). Conducting Research Interviews. Management Research Review, 35, 260-271. https://doi.org/10.1108/01409171211210154

Saldaña, J. (2015). The Coding Manual for Qualitative Researchers. Thousand Oaks, CA: Sage.

Santiago-Delefosse, M., Gavin, A., Bruchez, C., Roux, P., \& Stephen, S. L. (2016). Quality of Qualitative Research in the Health Sciences: Analysis of the Common Criteria Present in 58 Assessment Guidelines by Expert Users. Social Science \& Medicine, 148, 142-151. https://doi.org/10.1016/j.socscimed.2015.11.007

Sarkis, G., Tal, I., Giard, P., Vardy, A., Thibeault, C., \& Gross, W. J. (2016). Flexible and Low-Complexity Encoding and Decoding of Systematic Polar Codes. IEEE Transactions on Communications, 64, 2732-2745.

https://doi.org/10.1109/TCOMM.2016.2574996

Schaufeli, W. B., Shimazu, A., Hakanen, J., Salanova, M., \& De Witte, H. (2019). An Ultra-Short Measure for Work Engagement. European Journal of Psychological Assessment, 35, 577-591. https://doi.org/10.1027/1015-5759/a000430

Schmitt, A., Den Hartog, D. N., \& Belschak, F. D. (2016). Transformational Leadership and Proactive Work Behaviour: A Moderated Mediation Model Including Work Engagement and Job Strain. Journal of Occupational and Organizational Psychology, 89, 588-610. https://doi.org/10.1111/joop.12143

Scholl, H. J., Kubicek, H., Cimander, R., \& Klischewski, R. (2012). Process Integration, Information Sharing, and System Interoperation in Government: A Comparative Case Analysis. Government Information Quarterly, 29, 313-323.

https://doi.org/10.1016/j.giq.2012.02.009

Seifert, T. (2016). Involvement, Collaboration and Engagement: Social Networks through a Pedagogical Lens. Journal of Learning Design, 9, 31-45. https://doi.org/10.5204/jld.v9i2.272

Serini, S. A., Toth, E., Wright, D. K., \& Emig, A. G. (1997). Watch for Falling Glass... Women, Men, and Job Satisfaction in Public Relations: A Preliminary Analysis. Journal of Public Relations Research, 9, 99-118. https://doi.org/10.1207/s1532754xjprr0902 02

Singh, A., \& Gupta, B. (2015). Job Involvement, Organizational Commitment, Professional Commitment, and Team Commitment. Benchmarking, 22, 1192-1211.

https://doi.org/10.1108/BIJ-01-2014-0007

Singh, R. (2016). The Impact of Intrinsic and Extrinsic Motivators on Employee Engagement in Information Organizations. Journal of Education for Library and Information Science, 57, 197-206. https://doi.org/10.3138/jelis.57.2.197 
Smythe, W. E., \& Murray, M. J. (2000). Owning the Story: Ethical Considerations in Narrative Research. Ethics \& Behavior, 10, 311-336. https://doi.org/10.1207/S15327019EB1004_1

Sonnentag, S., \& Fritz, C. (2015). Recovery from Job Stress: The Stressor-Detachment Model as an Integrative Framework. Journal of Organizational Behavior, 36, S72-S103. https://doi.org/10.1002/job.1924

Soss, J. (2015). Talking Our Way to Meaningful Explanations: A Practice-Centered View of Interviewing for Interpretive Research. In D. Yanow, \& P. Schwartz-Shea (Eds.), Interpretation and Method (pp. 193-214). London, England: Routledge. https://doi.org/10.4324/9781315703275-10

Sotiriadou, P., Brouwers, J., \& Le, T. A. (2014). Choosing a Qualitative Data Analysis Tool: A Comparison of NVivo and Leximancer. Annals of Leisure Research, 17, 218-234. https://doi.org/10.1080/11745398.2014.902292

Swensen, S., Kabcenell, A., \& Shanafelt, T. (2016). Physician-Organization Collaboration Reduces Physician Burnout and Promotes Engagement: The Mayo Clinic Experience. Journal of Healthcare Management, 61, 105-127. https://doi.org/10.1097/00115514-201603000-00008

Thaler, R. H. (2016). Behavioral Economics: Past, Present, and Future. American Economic Review, 106, 1577-1600. https://doi.org/10.1257/aer.106.7.1577

Thomas, D. R. (2017). Feedback from Research Participants: Are Member Checks Useful in Qualitative Research? Qualitative Research in Psychology, 14, 23-41. https://doi.org/10.1080/14780887.2016.1219435

Thompson, C., \& Gregory, J. B. (2012). Managing Millennials: A Framework for Improving Attraction, Motivation, and Retention. Psychologist-Manager Journal, 15, 237-246. https://doi.org/10.1080/10887156.2012.730444

Tsai, A. C., Kohrt, B. A., Matthews, L. T., Betancourt, T. S., Lee, J. K., Papachristos, A. V. et al. (2016). Promises and Pitfalls of Data Sharing in Qualitative Research. Social Science \& Medicine, 169, 191-198. https://doi.org/10.1016/j.socscimed.2016.08.004

Unluer, S. (2012). Being an Insider Researcher While Conducting Case Study Research. Qualitative Report, 17, 1-14.

Vaismoradi, M., Jones, J., Turunen, H., \& Snelgrove, S. (2016). Theme Development in Qualitative Content Analysis and Thematic Analysis. Journal of Nursing Education and Practice, 6, 100-110. https://doi.org/10.5430/jnep.v6n5p100

Van Wingerden, J., Derks, D., \& Bakker, A. B. (2017). The Impact of Personal Resources and Job Crafting Interventions on Work Engagement and Performance. Human Resource Management, 56, 51-67. https://doi.org/10.1002/hrm.21758

Venkatesh, V., Brown, S. A., \& Sullivan, Y. W. (2016). Guidelines for Conducting Mixed-Methods Research: An Extension and Illustration. Journal of the Association for Information Systems, 17, 435-494. https://doi.org/10.17705/1jais.00433

Walumbwa, F. O., Muchiri, M. K., Misati, E., Wu, C., \& Meiliani, M. (2018). Inspired to Perform: A Multilevel Investigation of Antecedents and Consequences of Thriving at Work. Journal of Organizational Behavior, 39, 249-261.

https://doi.org/10.1002/job.2216

Waples, C. J., \& Brachle, B. J. (2020). Recruiting Millennials: Exploring the Impact of CSR Involvement and Pay Signaling on Organizational Attractiveness. Corporate Social Responsibility and Environmental Management, 27, 870-880.

https://doi.org/10.1002/csr.1851 
Watkins, D. C. (2012). Qualitative Research: The Importance of Conducting Research That Doesn't “Count.” Health Promotion Practice, 13, 153-158. https://doi.org/10.1177/1524839912437370

Wildavsky, A., \& Hammer, D. (2018). The Open-Ended, Semistructured Interview: An (Almost) Operational Guide. In A. Wildavsky (Ed.), Craftways: On the Organization of Scholarly Work (2nd ed., pp. 57-101). London, England: Routledge. https://doi.org/10.4324/9780203794517-5

Wiliam, D., \& Thompson, M. (2017). Integrating Assessment with Learning: What Will It Take to Make It Work? In C. A. Dwyer (Ed.), The Future of Assessment (pp. 53-82). London, England: Routledge. https://doi.org/10.4324/9781315086545-3

Wolgemuth, J. R., Erdil-Moody, Z., Opsal, T., Cross, J. E., Kaanta, T., Dickmann, E. M., \& Colomer, S. (2015). Participants' Experiences of the Qualitative Interview: Considering the Importance of Research Paradigms. Qualitative Research, 15, 351-372.

https://doi.org/10.1177/1468794114524222

Woods, K. (2016). Organizational Ambidexterity and the Multi-Generational Workforce. Journal of Organizational Culture, Communications and Conflict, 20, 95-111. https://www.abacademies.org/journals/journal-of-organizational-culture-communicati ons-and-conflict-home.html

Woods, M., Paulus, T., Atkins, D. P., \& Macklin, R. (2016). Advancing Qualitative Research Using Qualitative Data Analysis Software (QDAS)? Reviewing Potential versus Practice in Published Studies Using ATLAS.ti and NVivo, 1994-2013. Social Science Computer Review, 34, 597-617. https://doi.org/10.1177/0894439315596311

Xiong, L., So, K. K. F., Wu, L., \& King, C. (2019). Speaking Up Because It's My Brand: Examining Employee Brand Psychological Ownership and Voice Behavior in Hospitality Organizations. International Journal of Hospitality Management, 83, 274-282. https://doi.org/10.1016/j.ijhm.2018.11.006

Yazan, B. (2015). Three Approaches to Case Study Methods in Education: Yin, Merriam, and Stake. Qualitative Report, 20, 134-152. http://nsuworks.nova.edu/tqr/vol20/iss2/12

Yin, R. K. (2018). Case Study Research and Applications: Design and Methods (6th ed.). San Francisco, CA: Sage.

Zervas, G., Proserpio, D., \& Byers, J. W. (2017). The Rise of the Sharing Economy: Estimating the Impact of Airbnb on the Hotel Industry. Journal of Marketing Research, 54, 687-705. https://doi.org/10.1509/jmr.15.0204

Zielinski, D. E. (2017). The Use of Collaboration, Authentic Learning, Linking Material to Personal Knowledge, and Technology in the Constructivist Classroom: Interviews with Community College Faculty Members. Community College Journal of Research and Practice, 41, 668-686. https://doi.org/10.1080/10668926.2016.1220338 